\title{
PRICE STABILITY VS. LOW INFLATION IN GERMANY: AN ANALYSIS OF COSTS AND BENEFITS
}

Karl-Heinz Tödter

Gerhard Ziebarth

Working Paper 6170

http://www.nber.org/papers/w6170

\section{NATIONAL BUREAU OF ECONOMIC RESEARCH 1050 Massachusetts Avenue \\ Cambridge, MA 02138 \\ September 1997}

We thank the participants of the NBER conference, "The Costs and Benefits of Achieving Price Stability," held at the Federal Reserve Bank of New York, February 20-21, 1997. We would also like to thank S.P. Chakravarty, University of Bangor, UK, F. Seitz, Fachhochschule AmbergWeiden, Germany, and our colleagues in the Economics Department of the Deutsche Bundesbank, G. Coenen, H. Hansen, P. Heinelt, and P. Lämmel for their valuable comments and suggestions. All remaining errors are ours. This paper is part of NBER's research program in Monetary Economics. Any opinions expressed are those of the authors and not those of the Deutsche Bundesbank or the National Bureau of Economic Research.

(C) 1997 by Karl-Heinz Tödter and Gerhard Ziebarth. All rights reserved. Short sections of text, not to exceed two paragraphs, may be quoted without explicit permission provided that full credit, including $(\mathcal{C}$ notice, is given to the source. 
Price Stability vs. Low Inflation in Germany:

An Analysis of Costs and Benefits

Karl-Heinz Tödter and Gerhard Ziebarth

NBER Working Paper No. 6170

September 1997

Monetary Economics

\section{ABSTRACT}

We empirically investigate the costs and benefits of going from low inflation to price stability in the case of Germany. Recent empirical evidence on the sacrifice ratio suggests that the breakeven point at which the permanent benefits of reducing the trend rate of inflation by 2 percentage points exceeds the temporary costs in terms of output losses is below $0.3 \%$ of GDP. We analyze the welfare implications of the interactions even of moderate rates of inflation with the distorting effects of the German tax system. Four areas of economic activity are considered: intertemporal allocation of consumption, demand for owner-occupied housing, money demand, and government debt service. We estimate the direct welfare effects of reducing the rate of inflation as well as the indirect tax revenue effects. We find that reducing the inflation rate by 2 percentage points permanently increases welfare by $1.4 \%$ of GDP. Finally, the optimal rate of disinflation is considered.

Karl-Heinz Tödter

Research Department

Deutsche Bundesbank

PO Box 100602

D 60006 Frankfurt GERMANY

karlheinz.toedter@bundesbank.de
Gerhard Ziebarth

Research Department

Deutsche Bundesbank

PO Box 100602

D 60006 Frankfurt

GERMANY 


\section{Table of contents}

1. Price stability: too much of a good thing?

2. On the costs of disinflation

2.1 Monetary growth and inflation

2.2 The Bundesbank's monetary targeting strategy

2.3 Evidence on the sacrifice ratio

3. The benefits of price stability

3.1 Intertemporal allocation of consumption and saving

3.1.1 The welfare-theoretical approach

3.1.2 Interest rate and price effects

3.1.3 A first approximation

3.1.4 Quantity effects

3.1.5 The problem of indexation

3.1.6 The effect of social security contributions

3.2 Demand for owner-occupied housing

3.2.1 The price and quantity component

3.2.2 The indirect revenue effect

3.3 Money demand and seigniorage

3.3.1 The direct welfare effect

3.3.2 The indirect revenue effect

3.4 Government debt service

3.5 Overall benefit of price stability

3.6 The risks: some sensitivity calculations

3.7 On the optimal rate of disinflation

4. Summary and conclusions

References

Appendix A: The welfare-theoretical approach Appendix B: Taxation of corporate profit Appendix C: An overlapping generations model Appendix D: Assumptions for calculating the benefits Appendix E: Some sensitivity calculations Appendix F: An OLG model with transfers 
Price Stability vs. Low Inflation in Germany:

An Analysis of Costs and Benefits

"Are the benefits of disinflation

worth the costs?"

Croushore (1992, p. 3)

\section{Price stability: too much of a good thing?}

The notion that price stability should be the priority target of monetary policy has nowadays become widely accepted. This is due to the perception that high and volatile inflation rates distort economic allocation and reduce the long-term growth potential (Barro, 1995), whereas lasting monetary stability is conducive to economic growth, social welfare and social cohesion alike. By contrast, the consensus regarding the assessment of the "excess burden" associated with a moderate inflation rate, and of the cost (the "sacrifice ratio") of correcting such a rate, is much more fragile. ${ }^{1}$ In other words, are the benefits of price stability and the costs of disinflation still in reasonable proportion to one another, or should a moderate pace of inflation - rather than undue zeal in fighting inflation - be tolerated or even aimed at by economic policy makers? ${ }^{2}$

In the context of an in-depth analysis of the functions of money, Konieczny (1994, p. 34) comes to the following conclusion regarding the optimality of an inflation rate of zero: "The review of the theoretical arguments leads me to conclude that the optimal rate of inflation is zero." He emphasizes especially the adverse effects of inflation on the role of money as a unit of account (p. 32): "... the uniqueness of zero arises from the accounting role of money: it is, simply, infinitely easier to divide by one than by any other number. Only when the price level is stable can money perform properly its role as a stable unit of account and

1 In this connection, it should not be entirely overlooked that the costs of a disinflation could at bottom be charged to the preceding inflation, and would have to be offset against its gains.

2 S. Fischer (1994a, p. 40), for instance, argues: "The evidence points to an inflation range of $1-3 \%$ as being optimal... Once lower inflation is attained, the challenge for policy is to preserve those gains." Akerlof, Dickens and Perry (1996, p. 52) argue along similar lines: "Comparing low inflation rates with a zero inflation rate, we are convinced that the unemployment costs outweigh the costs of tax distortions. We fully appreciate the benefits of stabilizing inflation at a low rate, and advocate that as an appropriate target for monetary policy. But the optimal inflation target is not zero." 
standard of value. The desirability of a stable standard of measurement is evident from other arrangements: without exception, societies have chosen all other units of measure to be of constant value. Uniquely among all numbers, the credibility of zero can be defended on the grounds that it makes a pound (E) just like a pound (ib)!."

What is to be understood by "price stability" has been expressed in different ways. A. Greenspan (1989), the Chairman of the Federal Reserve Board in the United States, defines stable prices as "...price levels sufficiently stable so that expectations of [price level] change do not become major factors in key economic decisions." Decisions with a very short time horizon would probably turn out no different with an inflation rate of 2 to $3 \%$ from what they would be with price stability. On the other hand, decisions involving a long-term commitment or a long planning horizon must indeed take due account of the effects even of moderate inflation rates, and an average inflation rate of zero will actually impinge on decision-making if that rate is accompanied by high volatility. It also has to be borne in mind that the threshold for the perception of inflationary processes depends on past experience, and therefore may differ from country to country.

Anyway, inflation rates have been declining all over the world for a number of years. As measured by the consumer price index, the inflation rate in the G-7 countries averaged $3.9 \%$ p.a. between 1960 and 1973. In the wake of oil price hikes and an accommodating monetary policy on the part of some central banks, it rose to $9.7 \%$ p.a. between 1973 and 1979. During the eighties the average inflation rate still came to $5.5 \%$ p.a. But by 1995 the inflation rate of the G-7 countries was averaging $2.5 \%$ and, of the 27 OECD nations, 18 registered an inflation rate of less than $3 \%$ in 1995 . Besides the globally higher sensitivity to inflation as a result of the globalization of the financial markets (Issing, 1996a), in the member states of the European Union this trend probably also owes something to the envisaged monetary union.

Against this background, and in the light of the forthcoming debate on the operative objectives of monetary policy in the context of a monetary union in Europe, the important economic policy question arises for many countries: do the benefits of price stability warrant the costs of any further disinflation? In a 
comprehensive study for the United States, Feldstein put this question into concrete shape as follows: ${ }^{3}$

"If the true and fully anticipated rate of inflation (i.e. the measured rate of inflation minus two percentage points) has stabilized at two percent, is the gain from reducing inflation to zero worth the sacrifice in output and employment that would be required to achieve it?"

Even though our experience of inflation in the Federal Republic of Germany is different from that in the United States and the institutional framework here shows specific features, nevertheless monetary policy in this country has to face the same issue. The purpose of this paper is therefore to provide an empirically supported answer for Germany to the question raised by Feldstein. Against the background of the monetary policy strategy pursued by the Bundesbank, we first consider, in the ensuing chapter 2 , the costs of disinflation; in quantifying the "sacrifice ratio" we draw on recently published empirical investigations. With regard to the benefits of price stability, there have hitherto not been any such detailed analyses for Germany as that by Feldstein for the United States. The focal point of this paper is therefore chapter 3 , in which, building on the methodological foundation of Feldstein's approach, we examine the implications for macroeconomic welfare of the interaction even of moderate rates of inflation with the distorting effects of the tax system. ${ }^{4}$ First of all, we address, as part of an intertemporal approach, the impact of inflation on the allocation of consumption and saving. Then we investigate the implications of inflation for the demand for owner-occupied housing. Thereafter, we consider the distorting effects of inflation on money demand, which ever since Bailey's paper (1956) have been at the centre of the literature on the welfare effects of inflation. Finally, we contemplate the effects of inflation on public revenue from the money-creation process (seigniorage) and on government debt service. Chapter 4 offers a summary and some concluding remarks.

3 Feldstein (1996, p, 1). In the following we refer to this paper without any further details.

4 The fact that, for various reasons, the underlying tax systems play a particular part in the assessment of inflation effects has been stressed in a number of papers; see for example Feldstein, Green and Sheshinsky (1978), Tanzi (1980), King and Fullenton (1983), Sinn (1987) and Sievert et al. (1989). 
"Economists should be circumspect when attempting to estimate the costs of reducing the inflation rate." Lucas $(1990$, p. 70$)$

\section{On the costs of disinflation}

The costs of a lasting reduction in the rate of inflation depend on nominal and real rigidities on the overall goods and labour markets. Other significant factors are the stance of fiscal policy, the monetary policy strategy pursued by the central bank, and the degree of stability already reached. The Bundesbank's monetary policy has been based on a monetary targeting strategy for over twenty years. With the aid of this policy stance, it has proved possible (despite oil price hikes, monetary upheavals and tensions in the wake of German unification) to limit the average rate of inflation in those two decades to about $3 \%$ p.a., and thus to distinctly below the average level of the other industrial countries ( $5.5 \%$ p.a.).

\subsection{Monetary growth and inflation}

Partly owing to deregulation of the financial markets and to financial innovations, a number of countries have dispensed with the traditional monetary aggregates as indicators and intermediate targets of monetary policy. Even so, there continues to be a broad consensus that, over the long term, inflation is a monetary phenomenon. ${ }^{5}$ Pursuant to the quantity equation, the product of the money stock $(\mathrm{M})$ and the velocity of circulation $(\mathrm{V})$ equals the product of the price level $(\mathrm{P})$ and the real gross domestic product $(\mathrm{Y})$. Written logarithmically, the following applies: ${ }^{6}$

$$
m+v=p+y
$$

5 In the shorter to medium term, trends in the general price level may certainly depart from the path marked out by the growth of the money stock. Non-monetary price stimuli, temporary changes in the velocity of circulation of money or cyclical fluctuations in real income may be superimposed upon the key relationships for a considerable period. But this does not alter the basic fact that a process of sustained erosion of the purchasing power of money is a monetary phenomenon, for which economic policy is accountable.

6 In this chapter, small letters denote logarithms of variables and the symbol $\Delta$ stands for differences, i.e. $x=\ln (X)$ and $\Delta x=X-X_{-1}$. 
On the basis of this quantity equation, Hallman, Porter and Small (1989) define the equilibrium price level (P-star or $P^{*}$ for short) as the money stock per unit of real production potential $\left(Y^{\star}\right)$ at the equilibrium velocity of circulation $\left(V^{\star}\right)$ :

$$
p^{*}=m+v^{*}-y^{*}
$$

If a stable long-term money demand function

$$
m-p=\beta_{0}+\beta y+\varepsilon
$$

exists, ${ }^{7}$ with $\beta_{0}$ being either constant or a function of stationary variables and the random variable $\varepsilon$, with expectation zero, measuring deviations from long-term money demand, then the equilibrium velocity of circulation can be expressed as ${ }^{8}$

$$
v^{*}=-\beta_{0}+(1-\beta) y^{*}
$$

The equilibrium price level can now be written:

$$
p^{*}=m-\beta_{0}-\beta y^{*}
$$

As table 2.1 shows, the growth rates of equilibrium prices over fairly long periods agree pretty well with the actual inflation rates.

\section{Table 2.1: Monetary growth and inflation in Germany}

(Average growth rates of $\mathrm{M3}$, in \% p. a.)

\begin{tabular}{|c|c|c|c|c|}
\hline period & $\Delta \mathrm{m} 3$ & $\Delta \mathrm{y}^{*}$ & $\Delta \mathrm{p}^{*}+1$ & $\Delta \mathrm{p}$ \\
\hline $1970: 1-1979: 4$ & 10.4 & 3.2 & 5.8 & 5.5 \\
$1980: 1-1989: 4$ & 6.1 & 2.1 & 3.1 & 2.8 \\
$1990: 1-1996: 2^{++1}$ & 7.6 & 3.6 & 2.5 & 2.5 \\
\hline
\end{tabular}

+) $\Delta p^{*}=\Delta m 3-1,43 \Delta y^{*}$.

++1 Including the increase in $\mathrm{M} 3$ and in potential production due to unification.

Source: Issing and Tödter (1995) and our own calculations.

7 For Germany it can be assumed that, even after unification, there is a stable long-term money demand function; see Issing and Tödter (1995), Scharnagl (1996a, b) and the references listed there.

8 Issing and Tödter (1995) estimate the income elasticity of money demand ( $\beta$ ) in Germany at 1.43. Given a growth rate of real production potential averaging $2.2 \%$ p.a., this implies a trend decline in the velocity of cirroliation of iract undior 1 or n"s 
The price gap, i.e. the difference between the equilibrium price level and the actual price level, is composed of two components, viz. the degree of utilization of production potential (output gap) and the degree of liquidity (velocity gap):

$$
p^{\star}-p=\left(y-y^{\star}\right)+\left(v^{\star}-v\right)=\beta\left(y-y^{\star}\right)+\varepsilon
$$

In other words, pressure on prices is felt whenever production capacities are being heavily utilised and/or whenever cash holding is higher than is consistent with long-term money demand.

As empirical investigations for Germany show, the equilibrium price level and the actual price level are cointegrated. ${ }^{9}$ It follows from this that differences between the two variables are of a temporary nature and that disequilibria which have arisen will disappear again over time. The course of price movements can then be described (as is done here in stylised form) by an error correction equation:

$$
\Delta p=\Delta p^{e}+\lambda\left(p^{\star}-p\right)=\Delta p^{e}+\lambda \beta\left(y-y^{\star}\right)+\lambda \varepsilon
$$

The smaller the parameter $\lambda$, the more sluggishly prices respond to (goods- and money-market) disequilibria, and the higher real rigidity is. The expected inflation rate may be specified in this connection as a learning process in which inflation expectations adjust to changes in equilibrium prices,

$$
\Delta p^{e}=\gamma \Delta p_{-1}+(1-\gamma) \Delta p^{*}
$$

where the parameter $\gamma$ is a measure of nominal rigidity.

\subsection{The Bundesbank's monetary targeting strategy}

The Bundesbank's monetary targeting strategy primarily serves the objective of price stability. This strategy is geared to the long-term relationship between money

9 See Tödter and Reimers (1994), Scharnagl (1996a). 
and prices, a relationship which is soundly based on the quantity theory and proven empirically. ${ }^{10}$ Since 1988 the Bundesbank has used the money stock in the definition $\mathrm{M}^{11}$ as the indicator and intermediate target of its monetary policy. The annual target for the growth rate of the money stock $(\mu)$ is derived in accordance with a normative figure for the rate of inflation aimed at over the medium term $(\pi)$, and after taking due account of forecasts of the growth of production potential $\left(\Delta y^{*}\right)$ and of the trend change in the velocity of circulation $\left(\Delta v^{*}\right)$ :

$$
\mu=\pi+\Delta y^{*}-\Delta v^{*}=\pi+\beta \Delta y^{*}
$$

If the Bundesbank succeeds in getting the money stock to grow in line with this target $(\Delta m=\mu)$, then the equilibrium price level and - after the expiry of dynamic adjustment reactions - the actual price level increase at the rate $\Delta p^{*}=\Delta p=\pi$.

If the Bundesbank wanted to reduce the target inflation rate from $\pi$ to zero, it would durably have to lower the growth rate of the money stock to $\mu=\beta \Delta y^{*}$. In the event of uncertainty about the level of inflation, however, a distinction must be made between an inflation tarqet and a price-level tarqet. To illustrate the difference between the two targets, let it be assumed that the central bank manages to attain the inflation target of zero, except for an identically and independently distributed random variable $v_{\mathrm{t}}$ with expectation zero and variance $\sigma_{v}^{2}$. The price level $\left(p_{t}=p_{t-1}+v_{t}\right)$ then follows a random walk process with variance $\sigma_{v}^{2} T$ after $T$ periods. Even though the expected inflation rate for the next period is zero, the uncertainty about the price level in the more distant future may be very high. If, by contrast, the central bank is pursuing the target of stability of the price level, the variance of the price level is $\sigma_{v}^{2}$, regardless of the time horizon. The difference between the two strategies resides in the fact that, in the case of an inflation target, the central bank does not need to respond to a

10 On the theoretical and empirical foundations of monetary policy, see Issing (1992); on past experience of the monetary targeting strategy, see Issing (1995) and König (1996).

11 Currency in circulation and the sight deposits, time deposits for less than four years and savings deposits at three months' notice held by domestic non-banks - other than the Federal Government - at domestic credit institutions. 
temporary positive price shock, whereas, in the case of a price-level target, it is forced to usher in a period of deflation. ${ }^{12}$

\subsection{Evidence on the sacrifice ratio}

The potential costs of disinflation consist in output and employment losses during the period of running down inflation. The level of the costs depends on the slope of the Phillips curve (the macroeconomic supply function, respectively). If the longterm Phillips curve has a negative slope, any reduction in inflation results in lasting losses of output and employment; if the curve is vertical, then the output and employment losses are temporary.

In the above $\mathrm{P}^{\star}$-model, just as in neo-classical models, there need not be any disinflation costs at all if the central bank announces the target of disinflation credibly and if expectations respond immediately. Monetarist and neo-classical models exhibit a vertical Phillips curve in the long run, and thus temporary disinflation costs. The Keynesian models of the sixties postulated a lasting negative trade-off. According to neo-Keynesian theory, too, changes in monetary policy exert effects in real terms on account of rigidities in wage and price movements. ${ }^{13}$ The idea of a permanent trade-off between inflation and unemployment is, however, nowadays rejected by most economists: "There is a general acceptance among economists that the medium, and longer, term Phillips curve is vertical. Hence, there is no trade-off in the longer run between growth and inflation. Consequently, there is now also a consensus that the primary macropolicy objective of a central bank should be price stability."

In the literature, it is customary to express the costs of disinflation in terms of what is known as the "sacrifice ratio". The "output-sacrifice ratio" $(\sigma)$ measures the

12 See also Scarth (1994), Fiseher (1994a), von Hagen and Neumann (1996).

13 In simulations with small empirical models for the United States, Croushore (1992, p. 13) comes to the conclusion: "In a comparison of disinflation costs across the different models, the Monetarist-type model shows the lowest cost (actually a negative cost), the New-Classical-type model shows zero cost, the Keynesian-type model shows a high cost, and the PSTAR+ model shows a cost in between the high and low costs of the other models."

14 Goodhart (1992, p. 332). Taylor (1992, p. 13) argues along similar lines: "But if there is any change in the paradigm of macro-economics that most economists would agree with, it is that the trade-off view was mistaken." On the other hand, Akerlof, Dickens and Perry (1996, p. 52) argue that lasting real costs of disinflation exist on account of a 'deeply rooted downward nominal wage rigidity' in the economy: "The' unemployment costs are not one-time but, rather, permanent and substantial." 
cumulative output loss associated with the decline in the inflation rate. The "unemployment-sacrifice ratio" $\left(\sigma_{u}\right)$ denotes the corresponding rise in the unemployment rate. A link between the two concepts can be effected by the "Okun gap". The simplest way of determining "sacrifice ratios" is to measure for concrete historical periods of disinflation the cumulative output loss in relation to its trend movement or to the cumulative change in the unemployment rate. By this method, Schelde-Andersen (1992) computed sacrifice ratios for 16 OECD countries. He selected the time-span from 1979 to 1982 as a common period of disinflation in all countries. For Germany the ratio, relative to the unemployment rate, works out at $\sigma_{u}=6.4$, whereas the indicator measured in terms of output yields the value $\sigma=2.2 .{ }^{15}$ Ball (1994) uses a similar method, but identifies specific disinflation periods for each country. For Germany he obtains a ratio of $\sigma=3.6$ on the basis of quarterly figures for the period $1980: 1$ to $1986: 3 .{ }^{16}$ In a similar way to Ball, but with a different approach to estimating production potential, Herrmann (1996) computes a value of roughly $\sigma=2.6$ on the basis of quarterly data for the period from 1981:4 to $1986: 4$, whereas the ratio for the most recent period of disinflation from 1992:1 to $1995: 4$ works out at $\sigma=2.2$.

More analytically orientated approaches to the estimation of the costs of disinflation are mostly based on Phillips-type relations for wage or price inflation. In the context of the P-star model $(2.7 / 8)$ the output-sacrifice ratio can be measured as the relationship of the coefficients of nominal and real rigidity (see Schelde-Andersen, 1992, p. 112) :

$$
\sigma=\frac{\gamma}{\lambda \beta}
$$

In this model, a decline in monetary growth by one percentage point leads directly to an equally large decrease in the growth rate of equilibrium prices and ultimately also of the actual inflation rate. The expected inflation rate, however, initially declines by only $1-\gamma$, in line with (2.8). Hence, a gap of $\gamma$ percent between the actual decrease in the inflation rate and the expected decrease comes into being

\footnotetext{
15 For the longer periods from 1979 to 1985 or 1988 , the values for $\sigma$ were actually lower, at 1.2 and 1.6 respectively. This suggests that the costs of disinflation are temporary, and decrease over time.

16 With annual data for the period 1980 to 1986 he arrived at the value 2.1 .
} 
on account of nominal rigidities. In order to close this gap, the degree of capacity utilization must drop by $\gamma / \lambda \beta$ percentage points. In the long run, i.e. after expectations have come into line with the reduced monetary growth, output and the unemployment rate revert to their equilibrium values.

On the basis of price equations similar to (2.7), Schelde-Andersen (1992) estimates the value of $\sigma=3.3$ for the "output-sacrifice ratio" for Germany. A Phillips relationship for the wage inflation rate yields $\sigma_{u}=4.4$ for the "unemployment sacrifice ratio". These estimates also take account of the possibility of permanent disinflation costs, which might derive from the presence of hysteresis effects on the labour market. ${ }^{17}$

It is conspicuous that, in these studies, the costs of disinflation as estimated for Germany lie distinctly above the OECD average (see table 2.2). In a comparison by Schelde-Andersen (1992) on the basis of the sacrifice ratios for 16 OECD countries estimated by him, Germany comes last, as the country with the highest disinflation costs. One possible "explanation" might be that disinflation costs appear to be all the higher, the lower the initial inflation rate is: "A high initial rate of inflation seems to reduce the sacrifice ratio, thus suggesting that inflation is more costly to reduce when it is already very low."18

As the above remarks have illustrated, empirical estimates of sacrifice ratios involve a high degree of uncertainty. The results depend crucially on the method, the frequency of the data used, and a number of other factors. This is why simulations with a macroeconomic structural model form an alternative to such partial analytical estimates. ${ }^{19}$ Using the Bundesbank's multi-country econometric model ${ }^{20}$ Jahnke (1996) simulated a permanent increase in short-term interest

17 Schelde-Andersen (1992, p. 159) rejects the hypothesis of extreme hysteresis on the basis of estimates of the Phillips relationship for all countries except the United Kingdom. On the other hand, the null hypothesis that the unemployment rate follows a random walk process cannot be rejected for any of the 16 countries under review.

18 Schelde-Andersen (1992, p. 129). Other reasons for high disinflation costs relevant for Germany may have been a high real exchange rate (i.e. an unfavourable international competitive position) and low flexibility of the wage-bargaining process.

19 Schelde-Andersen (1992, p. 122) argues in favour of the model simulation approach: "Analytically. this is by far the most satisfactory method as it is comprehensive and exogenous factors are isolated. The sensitivity of costs to changes in the lag structure of the price and wage formation process can he estimated and it is also possible to illustrate the effect of changes in credibility."

20 A documentation of the model is included in Deutsche Bundesbank (1994a, 1996c). 
rates which leads to a permanent decline in the inflation rate. The estimation period for the forecasts of behavioural equations in the model extends from 1975:1 to $1995: 4$ and the simulation period comprises the time-span from 1997:1 to 2004:4. Over that span of eight years the sacrifice ratio, measured in terms of output, works out at about $\sigma=4$; this value is above the estimates obtained by partial analytical approaches.

Table 2.2 Estimates of the sacrifice ratio for Germany

\begin{tabular}{|l|c|c|c|}
\hline \multirow{2}{*}{ Method/Author } & \multirow{2}{*}{ Period/Data } & \multicolumn{2}{|c|}{ Sacrifice Ratio } \\
\cline { 3 - 4 } & & $\begin{array}{c}\text { Unemployment } \\
\left(\mathbf{O}_{u}\right)\end{array}$ & $\begin{array}{c}\text { Output } \\
\text { (o) }\end{array}$ \\
\hline Period analysis & $1979-82$ & 6.4 & 2.2 \\
Schelde-Andersen (1992) & $1980: 1-86: 3$ &. & 3.6 \\
Ball (1994) & $1981: 4-86: 4$ &. & 2.6 \\
Herrmann (1996) & $1992: 1-95: 4$ &. & 2.2 \\
Herrmann (1996) & & & 1.6 \\
unweighted OECD-average: & annual data & 2.5 & 1.5 \\
Schelde-Andersen (1992) & quarterly data &. & 0.8 \\
Ball (1994) & annual data &. & 3.3 \\
Ball (1994) & & & \\
\hline Phillips-approach & $1960-1990$ & 4.4 & 4.0 \\
Schelde-Andersen (1992) & 1997:1-2004:4 &. & \\
\hline Model simulation & & & \\
Jahnke (1996) & & & \\
\hline
\end{tabular}

Altogether, the available empirical evidence suggests that, in the past, the outputsacrifice ratio for Germany can hardly have been above $\sigma=4 .^{21}$ At that level it would have been about two to three times as high as the average of the other OECD countries. The empirical estimates suggest that the costs of disinflation (C) do not simply depend linearly on the disinflation rate but, rather, rise disproportionally fast:

$$
C=\sigma \pi^{1+\varphi}, \quad \varphi>0
$$

21 Feldstein calculates with an output-sacrifice ratio for the United States of 2 to 3. 
According to this equation, the reduction of the inflation rate by one percentage point - regardless of $\varphi$ - would imply an output loss amounting to $4 \%$ of the gross domestic product (GDP). Assuming $\varphi=1 / 2$, the reduction of the inflation rate by two percentage points, by contrast, would be associated with an output loss of $11.3 \% .22$

The available evidence suggests that the costs of disinflation are temporary, and they are incurred over a comparatively short period. ${ }^{23}$ By contrast, the benefits of price stability (G), expressed as a percentage of GDP, are permanent. To compare costs and benefits, we consider the present value of the benefits in all future periods. Given a discount rate of $\rho$, the present value of the benefits works out at $\mathrm{G} / \rho$. The reduction of inflation is beneficial if the permanent benefits of price stability exceed the annualized costs of disinflation:24

$$
\mathrm{G}>\rho \sigma \pi^{1+\varphi}
$$

Given a discount rate of $\rho=2.5 \%$ p.a. ${ }^{25}$ and the above-mentioned values for the other parameters $(\sigma=4, \pi=2, \varphi=1 / 2)$, the break-even point works out at $G=0.28$. Hence, to summarize the result of this chapter, the lasting benefits of price stability would have to be greater than $0.28 \%$ of GDP to warrant the costs of disinflation by two percentage points. In the next chapter we shall turn to the calculation of the benefits of price stability.

22 The reduction of inflation by three percentage points (from 4.5 to $1.5 \%$ p.a.) between 1992 and 1995 was accompanied by an output loss of 6 to $7 \%$. However, starting from this lower level, any further reduction in inflation is likely to involve higher costs.

23 Ball (1994) finds evidence suggesting that rapid disinflation is more favourable, whereas King (1996a) argues in favour of a gradual disinflation process.

24 We are well aware in this context that this criterion derived from a present value concept treats the future worse than the present. Hence there is a risk that too little importance is attached to future benefits and hence to future generations. This is why the discount rate, in cases of doubt, should tend to be set low, even though this remains ethically questionable from the point of view of inter-generational equity; sec Issing (1996b).

25 This rate is roughly in line with the difference between the real rate of interest under conditions of price stability and the growth rate of real potential production (see chapter 3 ). 


\section{The benefits of price stability}

The interaction between the tax system and inflation has repercussions on many areas of economic activity. In this chapter, we are concerned with estimating the welfare-theoretical benefits of price stability. In this context, we consider the steady state effects on the following economic activities:

1. The intertemporal allocation of consumption and saving

2. The demand for owner-occupied housing

3. Money demand and seigniorage

4. Government debt service

We base our quantification of the benefits of price stability on a steady state with a stable and fully anticipated inflation rate of $2 \%$ p.a. ${ }^{26}$ and examine the comparative static effects of lowering that rate to zero. We take into account both, the direct benefits of reducing inflation-induced distortions and the indirect welfare effects emanating from the change in tax revenue owing to the lowering of the inflation rate, given the prevailing expenditure stance of the public authorities.

Other advantages of price stability are not included in our computation, although we certainly do not deem them to be insignificant. ${ }^{27}$ The avoidance of distortions due to inflation is accompanied by an enhancement of performance incentives and a more efficient operation of economic processes. This includes the greater informative value of relative prices, a better-balanced financing structure, improved economic efficiency and higher productivity. Furthermore, redistribution processes and redistribution conflicts due to inflation would be avoided, and the wastage of scarce resources in order to side-step the adverse effects of inflation would cease. In addition, under conditions of price stability the uncertainty

26 What is meant is an effective inflation rate of $2 \%$, i.e. an inflation rate after adjustment for statistical measuring errors.

27 See the survey in Edey (1994), Fischer (1994b) and King (1996b). 
engendered by inflation would diminish. ${ }^{28}$ The extent to which such improved underlying conditions influence the long-term growth path is outside the scope of our investigation. But, as is shown in models of the new growth theory, price stability can also contribute to lastingly stronger economic growth (Black et al. 1994).29

In computing the welfare effects, we are largely following the approach adopted by Feldstein, although we have made a number of modifications to take account of the special features of the German tax system. Moreover, in calculating the indirect revenue effects, we do not set the parameter which measures the deadweight loss of the tax system exogenously but derive it from the model.

\subsection{Intertemporal allocation of consumption and saving}

The taxation of capital and of the earnings accruing from it involves welfare losses. The existing tax system admittedly gives rise to such distortions even if price stability obtains. However, the interaction of inflation and distortionary taxation results in an additional welfare loss, a "deadweight loss", which derives from the fact that inflationary processes drive a "tax-inflation wedge" between the gross yield and the net return on capital. This - as we shall show - reduces the real return on investment, saving is impaired and the intertemporal allocation of consumption is distorted. Similarly, the elimination of a positive inflation rate is associated with deadweight gains.

\subsubsection{The welfare-theoretical approach}

The starting point of the analysis is a two-period overlapping generations model. In this model the following fundamental relationship exists between the savings of the young generation $(\mathrm{S})$ and their later consumption in old age $(\mathrm{C})$ :

28 This uncertainty depends, as mentioned above, in part on whether the central bank is aiming at the target of an inflation rate of zero or at price-level stability; see section 2.2 .

29 Even a small increase in the pace of growth would generate a huge effect over time. If, in the event of a decline in the inflation rate of 2 percentage points, the real growth rate rose by 0.2 percentagc points (this is the magnitude that Grimes (1996) ascertained empirically in a cross-section analysis for 27 countries), given a difference of 2.5 percentage points between the real rate of interest and the real growth rate in the starting period, the present value of the increase in real output amounts to three times the current GDP. 


$$
S=p C
$$

In this intertemporal budget equation, $p$ denotes the price of future consumption. Given a real net payment of interest on savings at a rate of $r$ over a period of $T$ years (i.e. over one generation), the price of future consumption, expressed in terms of units of present consumption, is:

$$
p=(1+r)^{-T}, \quad \text { with } \quad \varepsilon_{p r}=-T \frac{r}{1+r}
$$

As the elasticity $\varepsilon_{\mathrm{pr}}$ indicates, an increase in the real net yield on savings leads to a decline in the price of retirement consumption. The price-quantity combinations in the three szenarios under investigation are designated as follows:

$$
\begin{array}{ll}
\text { no tax, no inflation: } & \left(p_{0}, C_{0}\right) \\
\text { tax, no inflation: } & \left(p_{1}, C_{1}\right) \\
\text { tax and }(2 \%) \text { inflation } & \left(p_{2}, C_{2}\right)
\end{array}
$$

As is explained in more detail in Appendix $\mathbf{A}$ and illustrated by Figure A1, under the welfare-theoretical approach to the quantification of the benefits of price stability, the following quantities (areas) are relevant:

$$
\begin{aligned}
& A=\frac{1}{2}\left(p_{1}-p_{0}\right)\left(C_{0}-C_{1}\right) \\
& B=\left(p_{1}-p_{0}\right)\left(C_{1}-C_{2}\right) \\
& C=\frac{1}{2}\left(p_{2}-p_{1}\right)\left(C_{1}-C_{2}\right) \\
& D=\left(p_{1}-p_{0}\right) C_{2} \\
& E=\left(p_{2}-p_{1}\right) C_{2}
\end{aligned}
$$

In the absence of taxes and inflation, an economic agent may save the amount $\mathrm{S}_{0}$ at the price $p_{0}$ in order to achieve the consumption level $C_{0}$ in old age. By the 
introduction of a tax on investment income, the real yield declines and the price of consumption rises to $p_{t}$, while the consumption level falls to $C_{1}$. As a result the consumers' surplus decreases to the extent of the area $A+B+D$, and a tax yield amounting to the area $B+D$ comes into being. The difference between the two areas, viz. the (Harberger) triangle $\mathbf{A}$, in terms of welfare economics, a deadweight loss of taxation.

If, under the existing tax system, inflation is added (i.e. if the inflation rate rises from zero to, say, $\pi=2 \%$ ), then the interaction of distortionary taxes and inflation leads, as will be demonstrated below, to a decline in the real net yield and a further rise in the price of future consumption to $p_{2}$, whereas the level of consumption falls to $\mathrm{C}_{2}$. Hence the consumers' surplus drops by the area $\mathrm{C}+\mathrm{E}$, whereas the tax yield changes by $\mathbf{B}-\mathbf{E}$. The difference is again a deadweight loss, but its magnitude is no longer in line only with the "small triangle" of traditional welfare theory, which arises through the 'disruption' of a 'first best' equilibrium. The deadweight loss of inflation is, rather, the trapezoid $B+C$, which may be much bigger, and which comes into being through the extension, due to inflation, of the already existing tax-induced distortion. On the return to price stability, there arises a correspondingly large deadweight gain.

As will be demonstrated below, the change in the tax yield at zero inflation as measured by the area $\mathbf{B}-\mathbf{E}$ is negative, i.e. a shortfall in tax revenue occurs owing to the disappearance of inflation. Generally it is assumed that the changed tax revenue is offset by a lump-sum tax, with a neutral effect in terms of welfare accounting. This, however, is an unrealistic assumption. In actual fact, it is to be expected that the shortfall in tax revenue is offset by the introduction, or raising, of other taxes (at a given level of expenditure), which in their turn are associated with welfare-theoretical deadweight losses. If these offsetting taxes involve a deadweight loss per D-Mark of tax revenue amounting to $\lambda$, the welfare gain of price stability will decrease to the extent of $\lambda(\mathbf{B}-\mathbf{E}) \cdot{ }^{30}$ The overall benefit of a

30 The parameter $\lambda$ can therefore be regarded as a measure of inefficiency of taxation; in the best case, i.e. in one with offsetting neutral taxes (lump sum taxes), $\lambda$ would equal 0 . It is nevertheless far away from being self-evident to make such compensatory changes in tax revenues, because one could object that the former inflation process softened the budget constraint of the government. 
reduction in inflation then constitutes the sum of the direct deadweight gain and the indirect income effect:

$$
\mathrm{G}_{C}=(\mathbf{B}+\mathbf{C})+\lambda(\mathbf{B}-\mathbf{E})
$$

However, the form in which the tax losses due to the reduction in inflation would be offset, and the associated welfare effects, remain an open question. Feldstein assumes that $\lambda=0.4$ would be a reasonable "benchmark" value for the shadow price of taxation. By contrast, we calculate the parameter $\lambda$ directly from our model. More precisely, we approximate the deadweight loss of the German tax system by the ratio

$$
\lambda_{C}=/(\mathbf{B}+\mathbf{D})
$$

which is the deadweight loss of capital income taxation per D-Mark tax revenue in the regime of price stability. The overall inefficiency of the regime with tax and inflation is also of interest. It can be expressed by

$$
\lambda_{\mathrm{C}+\pi}=(\mathrm{A}+\mathrm{B}+\mathrm{C}) /(\mathrm{D}+\mathrm{E})
$$

while the marginal inefficiency of inflation-induced taxes is defined by

$$
\lambda_{\pi}=(\mathbf{B}+\mathbf{C}) /(\mathbf{E}-\mathbf{B})
$$

\section{(see Figure A1 in Appendix A).}

The above-mentioned areas are, in each case, the product of a price component and a quantity component, which will have to be measured in the next sections.

\subsubsection{Interest rate and price effects}

Given a real yield before tax of $r_{0}$ and a tax rate on investment income of $\Theta$, in the event of an inflation rate of zero the real net yield amounts to 


$$
r_{1}=r_{0}(1-\Theta)
$$

Given a positive inflation rate $(\pi=2 \%)$, investment income is composed of a nominal and a real component. If the simple Fisher theorem applies, and if both components of investment income are taxed at the same rate, then the real net yield, in the case of inflation, approximates to: ${ }^{31}$

$$
r_{2}=\left(r_{0}+\pi\right)(1-\Theta)-\pi=r_{1}-\pi \Theta
$$

That is to say, the real rate of interest is reduced owing to the inflation by the amount $\pi \Theta .32$ In principle, this adverse effect of inflation on real net interest rates could be prevented or lessened by indexing the tax system. But it is also conceivable that market adjustment reactions might ensure that the nominal interest rate $(R)$ does not only increase to the extent of the inflation rate, as in the simple Fisher theorem, but rather responds disproportionately fast: $d R / d \pi>1.33$ To take this into account, we write the real net interest rate in the case of inflation as:

$$
r_{2}=\left(r_{0}+\frac{1-\omega}{1-\Theta} \pi\right)(1-\Theta)-\pi=r_{1}-\pi \omega
$$

The parameter $\omega$, which will be very important hereafter, reflects the decline in the real yield after tax that would result if the inflation rate were increased by one percentage point; it can be interpreted as the effective marginal tax rate on the inflation-induced component of investment income. If $\omega=\Theta$, the real and the inflation-induced component of investment income are treated alike in tax terms,

31 Furthermore, it is assumed that the gross real interest rate does not include any inflation-induced risk premium and that a Tobin effect (asset substitution between fixed capital and money on account of inflation), if any, can be disregarded.

32 For instance, given a gross yield of $10 \%$ and a tax rate of $50 \%$, the net yield under conditions of price stability would be $5 \%$. With $2 \%$ inflation, the nominal gross yield would rise to $12 \%$ but the real net yield would fall to $4 \%$. It should be bome in mind in this connection that the coupon is subject to tax, with the result that, if the buying rate is above par, the net real interest rate on final maturity decreases even further (et vice versa).

33 See Darby (1975) and Feldstein (1976). Given $d R / d p=1 /(1-\Theta)$, the effect of inflation on the real net yield would be eliminated entirely. 
and inflation exerts an unabated impact on the real net yield. If $\omega=0$, inflation has no effect on the real net yield. After the insertion of (3.12), (3.14) can also be expressed as

$$
r_{2}=r_{0}(1-t)
$$

where $t$ is the effective average tax rate under conditions of inflation:

$$
t=\Theta+\frac{\omega}{r_{0}} \pi
$$

For Germany, the average real gross yield on fixed capital between 1991 and 1995 works out at $r_{0}=10.8 \%$, according to internal computations by the Bundesbank. ${ }^{34}$

The profits of German corporations distributed to domestic individuals are subject to a variety of taxes: trade tax (on returns and capital), corporation tax, investment income tax, property tax, income tax and the solidarity surcharge (to finance German reunification) ${ }^{35}$. But, in contrast to the situation in the United States, corporation tax and investment income tax (as well as the applicable solidarity surcharge) are set off against income tax, in the form of a tax credit. As can be seen from Appendix B, the average tax burden in this model calculation amounts to $\mathrm{t}=60.7 \% .36$ Thus, it follows from (3.15) that the real net yield is $r_{2}=10.8(1-0.607)=4.24 \%$.

This yield was achieved with an average inflation rate of $3.3 \%$ between 1991 and 1995. If it is assumed that the inflation rates recorded in the statistics overstate the

34 The gross income of non-financial enterprises (excluding also the housing sector, agriculture and fishery as well as imputed entrepreneur's eamings) in relation to net fixed capital at replacement costs is used as an indicator of the fixed capital yield. In order to prevent distortions on account of German unification, we will henceforth use west German data (old Länder) for the period from 1991 to 1995 where necessary.

35 The following calculations refer to the stylised tax regulations prevailing in 1995 and 1996. Starting in 1997 the investment income tax was cancelled; furthermore the abolition of the trade tax on capital is envisaged.

36 The average tax burden on the retained profits of a domestic corporation works out at $64.3 \%$, and that on the earnings of a partnership at a calculated rate of $55.3 \%$. 
actual increases in prices, ${ }^{37}$ then it is possible to calculate for the period in question, as Feldstein did for the United States, an average effective inflation rate of $\pi=2 \%$. The real net yield which would result in the absence of inflation can now be computed from (3.14):

$$
r_{1}=r_{2}+\pi \omega
$$

In order to determine the effective tax rate on nominal investment income $(\omega)$, we take account of the depreciation and the interest paid in the corporate sector and the interest received in the private sector: ${ }^{38}$

$$
\omega=\tau z-\tau b+\tau b^{\prime}
$$

In this equation, $\tau$ is the marginal tax rate for distributed corporate profits and $\tau$ ' is the (weighted) marginal income tax rate, including the solidarity surcharge. Moreover, $\mathbf{z}$ denotes the present value of tax depreciation, $\mathrm{b}$ the debt ratio of enterprises (the ratio of borrowed capital bearing interest at market rates to total capital) and b' the ratio of shares and debt securities in households' portfolios.

Since the depreciation is effected in order to calculate the taxable earnings on the basis of historic purchase prices (and not of replacement costs), inflation reduces the present value of depreciation ( $z$ ) and thus increases the effective tax rate. Auerbach (1978) showed that capital costs increase by the amount $\tau z$ if the inflation rate rises by one percentage point. The present value depends on the write-off period for tax purposes of the asset in question $\left(T_{5}\right)$, as well as on the depreciation method used and the discounting factor (nominal market interest rate after tax). As an approximation to the customary depreciation allowances, we use the formula

37 The consumer price index is likely to be upwardly distorted on account of a product substitution bias, a quality bias, a new goods bias and an outlet substitution bias; see Edey (1994).

38 In the private sector Feldstein also takes account of the effect of taxing capital gains, but this plays only a subordinate role under German tax legislation (in income taxation there are so-called speculation periods of six months and two years, respectively, for securities transactions and real property transactions). 


$$
z=\frac{2 / T_{s}}{r_{2}+\pi+2 / T_{s}}
$$

As the table in Appendix B shows, with the assumptions underlying our considerations the marginal tax burden on the distributed profits of a domestic corporation amounts to $\tau=48 \% .{ }^{39}$ If, moreover, one assumes an average writeoff period of $T_{s}=10$ years, given a real net yield of $r_{2}=4.24 \%$, as calculated above, and an inflation rate of $2 \%$, the present value of tax depreciation works out at $z=0.76$, that is to say, the reduction of the inflation rate by one percentage point would increase the real yield by $\tau z=0.37$ percentage points.

This positive effect on the real yield is counteracted by the tax deductibility of nominal interest costs. If every percentage point of inflation increases the nominal cost of corporate indebtedness by one percent, 40 then the real interest costs remain unchanged, whereas the enterprise obtains an additional deduction option when calculating its taxable profits. In the case of an inflation rate of zero, this relief of earnings would disappear. Given a corporate debt ratio of $b=45 \%, 41$ the reduction of the inflation rate by one percentage point leads to a decline in the real yield of $\tau b=0.22$ percentage points.

In the private sector, income taxes are likewise related to nominal interest income, which gives rise to a taxation of fictitious profits. Hence a reduction in the inflation rate lowers the effective tax rate and raises the real net yield. If the real gross yield is independent of the level of the inflation rate, then the real net yield falls to the extent of the marginal tax rate. On the basis of a ratio of shares and debt securities to households' net financial assets of $b^{\prime}=43 \%, 42$ and on the assumption of a weighted marginal income tax rate (including the solidarity surcharge) of $\tau^{\prime}=37.6 \%, 43$ in the event of a decline in the inflation rate of one

39 The distributed profits of a partnership are subject to a marginal tax burden of identical size. On the other hand, the marginal tax burden on the retained profits of a corporation, at $57 \%$, is actually even higher; see Appendix B.

40 See Feldstein (p. 17), Mishkin (1992).

41 This figure refers to the average corporations' liabilities other than their provisions, see Deutsche Bundesbank (1994b, p. 16).

42 The net financial assets are calculated without mortgage debts. See Deutsche Bundesbank (1996a) and Deutsche Bundesbank (1996b, pp. 25 to 47 ).

43 This rate results from a (weighted) income tax rate of $35 \%$ and a solidarity surcharge of $7.5 \%$; see Appendix B. 
percentage point, a rise in real net interest rates of $\tau^{\prime} b^{\prime}=0.16$ percentage points occurs.

If one combines these three components, the outcome is an effective marginal tax rate on inflation-induced capital income of $\omega=0.31$. The upshot of this, in accordance with equation (3.14'), for the real net yield with an inflation rate of zero is: $r_{1}=4.24+2 * 0.31=4.87 \%$. According to this estimate, the real net yield would rise by 0.63 percentage points on account of the disappearance of an inflation rate of $2 \%$. 44

If one assumes a time-span of $T=27$ years for the average period elapsing between the savings of the young generation and their consumption in old age, 45 the following prices result from (3.2) for retirement consumption in the three aforementioned scenarios:

\begin{tabular}{|c|c|c|}
\hline & Interest rate & Price \\
\hline $\begin{array}{l}\text { no tax, no inflation: } \\
\text { with tax, no inflation: } \\
\text { with tax and }(2 \%) \text { inflation: }\end{array}$ & $\begin{array}{l}r_{0}=10.80 \% \\
r_{1}=4.87 \% \\
r_{2}=4.24 \%\end{array}$ & $\begin{array}{l}p_{0}=0.0627 \\
p_{1}=0.2771 \\
p_{2}=0.3255\end{array}$ \\
\hline
\end{tabular}

\subsubsection{A first approximation}

Given the interest rates and price changes between the two regimes derived above, we are now able to give a first and rough estimate of the benefits of price stability. For this purpose we need an approximation of the change in retirement consumption $\left(C_{1}-C_{2}\right)$. From equation (3.1) the following expression for the consumption reaction can be derived:

$$
d C=\frac{S}{p} \frac{d p}{p} \varepsilon_{C p} \quad \text { resp. } C_{1}-C_{2}=\frac{p_{1}-p_{2}}{p_{2}} C_{2} \varepsilon_{C p}
$$

\footnotetext{
44 For the United States, Feldstein ascertaines a rise of 0.49 percentage points in the real net yield.

45 For the United States, Feldstein assumes a period of 30 years.
} 
where $\varepsilon_{\mathrm{Cp}}$ denotes the compensated elasticity of retirement consumption with respect to its price. ${ }^{46}$

Using the Slutsky decomposition and equations (3.1) and (3.2), the unobservable compensated price elasticity of retirement consumption $\left(\varepsilon_{c_{p}}\right)$ and the uncompensated interest rate elasticity of the savings of the young generation $\left(\eta_{\mathrm{Sr}}\right)$ are related through

$$
\varepsilon_{C p}=-\left(1-\sigma_{y}-\eta_{S p}\right), \text { with } \eta_{S p}=-\eta_{S r} \frac{1+r}{r T}
$$

where $\sigma_{y}$ is the income effect caused by a change in the interest rate; it is measured by the ratio of the savings of the young generation to their (exogenous) wage and salary income. In this section, we assume that savings are completely interest-inelastic and we ignore the income effect, resulting in $\varepsilon_{\mathrm{Cp}}=-1$.

As equation (C.9) of Appendix $\mathbf{C}$ shows, in the overlapping generations model the following link exists between the savings of the young generation $\left(S_{2}\right)$ and aggregate private saving (S):

$$
S=S_{2}(1-q), \quad q=(1+n+g)^{-T}
$$

In this equation, $\mathrm{n}+\mathrm{g}=2.2 \%$ is the longer-term average growth rate of real wages and salaries (and at the same time of the real domestic product) between 1986 and 1994.47 If one also bears in mind that private saving accounts for a share of $S=9.3 \%$ in GDP, savings of the young generation is estimated as: $S_{2}=20.9 \%$ of GDP, giving $C_{2}=S_{2} / p_{2}=64.1 \%$ of GDP. 48

46 Regarding the compensated demand function, see Silberberg (1978) and Varian (1984).

47 In this case, the average rate of the last five years is distorted downwards owing to German unification, which is why we use a 10 -year average here.

48 Alternatively, the savings of the young generation can also be determined using equation (C5) of Appendix $\mathrm{C}$. In this way, the estimated value of the share of savings of the young generation in the gross national product likewise works out at $\mathrm{S}_{2}=20.9 \%$. 
Plugging this value into equation (3.19) and recalling from the previous section that we estimated the relative change of the price for retirement consumption as $\left(p_{1}-p_{2}\right) / p_{2}=-14.9 \%$, we obtain the following increase in retirement consumption: $\mathrm{C}_{1}-\mathrm{C}_{2}=9.55 \%$ of GDP. In conjunction with equations (3.4) and (3.5) we obtain $2.05+0.23=2.28 \%$ of GDP as a rule of thumb estimate of the trapezoid area $\mathbf{B}+\mathbf{C}$.

To make the factors behind this calculation more explicit, we may alternatively use the following simple but instructive formula

$$
\mathbf{B}+\mathbf{C} \approx \mathrm{S}_{2} \frac{p_{1}-p_{0}}{p_{1}} \frac{p_{2}-p_{1}}{p_{2}}=0.209{ }^{\star} 0.774{ }^{\star} 0.149=2.4 \% \text { of GDP }
$$

which largely confirms the result derived above. Equation (3.22) decomposes the welfare gains of price stability into three factors. The first, savings of the young, is the base for capital income taxation. The second factor is the change of the price of retirement consumption due to capital income taxation, and the third factor measures the price increase due to $(2 \%)$ inflation. This factor itself can be decomposed approximatively into the rate of (dis-) inflation $(\pi)$, the implicit inflation tax rate $(\omega)$ defined in equation (3.14) and the average number of years until retirement $(T)$ :

$$
\frac{p_{2}-p_{1}}{p_{2}} \approx \pi \omega T
$$

Hence, the welfare costs of inflation tend to be high if the savings rate is high, if capital income is taxed heavily, and/or if the tax system is not indexed. All of these factors apply to the German economy and may explain - besides still deeply rooted historical experiences with hyperinflation and more recent inflation periods in the seventies and early eighties - the pronounced inflation aversion resp. stability culture of the German population. 
Thus on the basis of this first approximation we may conclude that the elimination of a low inflation rate of $2 \%$ produces a direct welfare qain of more than $2 \%$ of GDP. This ready reckoner admittedly neglects any substitution effects and income effects of the change in interest rates. Moreover, the welfare effects of compensatory tax revenue changes are not yet included. This is the subject of the next section.

\subsubsection{Quantity effects}

For a more exact calculation of the quantity effects we need the uncompensated interest elasticity of savings $\left(\eta_{s r}\right)$ as well as the savings ratio of the young generation $\left(\sigma_{y}\right)$. As outlined in more detail in Appendix C, from the overlapping generations model we obtain $\eta_{\mathrm{Sr}}=0.25$ for the uncompensated savings elasticity, implying $\eta_{\mathrm{Sp}}=-0.228$. Since on average gross wages account for $56 \%$ of GDP, we get $\sigma_{y}=S_{2} / G D P=0.209 / 0.56=0.374$. Therefore, equation (3.20) yields the value $\varepsilon_{C p}=-(1-0.374-(-0.228))=-0.854$ for the price elasticity of retirement consumption. This in turn yields $C_{1}-C_{2}=(-0.149) * 0.642 *(-0.854)=8.16 \%$ of GDP for the change in retirement consumption and, by the same procedure, $\mathrm{C}_{0^{-}}$ $\mathrm{C}_{1}=49.9 \%$ of GDP. Finally, equation (3.1) provides the value $\mathrm{C}_{2}=64.3 \%$ of GDP. ${ }^{49}$ Combining the estimated price and quantity effects, the areas $\mathbf{A}$ to $\mathbf{E}$ can now be quantified from (3.3) to (3.7):

$$
\begin{aligned}
& \mathbf{A}=5.35 \% \text { of GDP } \\
& \mathbf{B}=\quad \mathbf{1 . 7 5} \% \text { of GDP } \\
& \mathbf{C}=\mathbf{0 . 2 0} \% \text { of GDP } \\
& \mathbf{D}=13.79 \% \text { of GDP } \\
& \mathbf{E}=3.11 \% \text { of GDP }
\end{aligned}
$$

Owing to the disappearance of the distortions in the intertemporal allocation of consumption and saving alone, the direct welfare gain of price stability amounts to $\mathrm{B}+\mathrm{C}=1.95 \%$ of the gross domestic product.

49 This assumes that the share of savings of the young generation is roughly the same under both regimes, i.e. both with and without inflation. 
However, tax revenue would decrease by $\mathrm{B}-\mathrm{E}=-1.36 \%$ of GDP. The deadweight loss per D-Mark of tax revenue on the taxation of investment income is estimated at $\lambda_{C}=A /(B+D)=5.35 / 15.54=0.34$. If one assumes that the above-computed tax loss in the case of price stability is offset by raising taxes with a similar shadow price, then the overall benefit of reducing inflation amounts on balance, pursuant to equation (3.8), to

$$
G_{C}=1.95+0.34 *(-1.36)=1.48 \% \text { of GDP }
$$

\subsubsection{The problem of indexation}

The shadow price of capital income taxes under conditions of inflation $\lambda_{C+\pi}=(A+B+C) /(D+E)=0.43$, as calculated from $(3.10)$, is distinctly higher than under price stability, which is $\lambda_{\mathrm{c}}=0.34$. The reason is the exceptionally high shadow price of the implicit inflation tax, defined in (3.11), which turns out as $\lambda_{\pi}=(\mathbf{B}+\mathbf{C}) /(\mathbf{E}-\mathbf{B})=1.43$, demonstrating yet again that inflation is an extremely inefficient way of generating government revenue. Hence, the priniciple of causation as well as welfare analysis suggest that monetary policy and not tax policy should be primarily responsible to eliminate the highly inefficient inflation $\operatorname{tax}$.

Nevertheless, it is sometimes argued that the welfare gain deriving from the reduction of inflation could be accomplished equally well by indexing the tax system. This argument is correct only in principle. To attain the same real yield under conditions of inflation as in a state of price stability, i.e. $r_{1}$, the tax rate would have to be made dependent on the inflation rate. The taxation of capital income would have to be shaped in such a way that the effective average tax rate was a diminishing function of the (true, not necessarily the measured) inflation rate, i.e. the following equation would have to apply:

$$
\Theta=t-\frac{\omega}{r_{0}} \pi=0.607-2.87 \pi
$$


Given an inflation rate of $2 \%$, the average tax rate of $t=60.7 \%$ would have to fall by 5.7 percentage points to $\Theta=55 \%$ in order to attain the same effective taxation as in the case of price stability. Since $r_{0}$ is not necessarily constant, and since $\omega$ likewise hinges on variables rather than constants, the indexation formula would constantly have to be adjusted. That is only one of many reasons why indexation is not a practicable alternative to price stability. 50 In the absence of inflation, however, the lower effective tax rate would materialise "of its own accord".

\subsubsection{The effect of social security contributions}

The analysis so far implicitly assumed that a fully funded system is in place for providing old age pensions. This assumption allowed us to keep the model relatively simple. However, it would be interesting to check whether the results obtained above survive if we take into account that actually many retirees receive a significant amount of exogenous income through an unfunded (,pay as you go") system.

For this purpose we assume that the young pay a fraction of their gross wages as contributions to the social security system $(\gamma W)$, receiving $\gamma$ W/q when retired, where $q=(1+n+g)^{-\top}$ and $n+g$ is the implicit rate of return in a "pay as you go" system. (In a fully funded system the rate of return would be r.) Moreover, we assume that the old generation leaves "indirect bequests" $(R)$ to the government and the young generation receives transfers $(Z)$ from the government which are not directly linked to R. As explained in Appendix F, the budget constraint of the extended overlapping generations model linking savings $(S)$ of the young to their retirement consumption (C) changes from equation (3.1) to

$$
S=p C-\frac{p}{q}(\gamma W-R)
$$

From national accounts data for the period 1991 to 1995 we get the value $\gamma=0.15$. The parameter $\mathrm{R}=0.10 \mathrm{GDP}$ was calibrated such that the model

50 A more detailed discussion of the problems posed by the indexation of the tax system will be found in Feldstein. pp. 45 to 50. 
approximately reproduces the income and expenditure account of the private sector for the stated period.

Perhaps surprisingly, these extensions practically do not change the results. The reduced distortion of intertemporal allocation of consumption yields benefits amounting to

$$
\mathrm{G}_{\mathrm{C}}=1.87+0.40^{*}(-0.91)=1.50 \% \text { of } \mathrm{GDP}
$$

which is almost the same result as that obtained on the basis of the simpler model.

\subsection{Demand for owner-occupied housing}

Owner-occupied dwellings are given preferential treatment in income taxation, although they are fundamentally regarded as a consumer good. ${ }^{51}$ Nevertheless some parts of the acquisition costs are allowed to be deducted from tax, while the notional rental value (which represents implied investment income) is not subject to taxation. (In contrast to the situation in the United States, however, debt interest cannot be deducted from tax.) This results in a subsidy-induced distortion of the demand for residential property as well as in a major shortfall in tax revenue. 52

For reasons similar to those in the preceding chapter with regard to the deadweight loss of inflation, the following trapezoid measures the inflation-induced deadweight loss in the case of owner-occupied housing:

$$
G_{H 1}=\left[\left(R_{0}-R_{1}\right)+\frac{1}{2}\left(R_{1}-R_{2}\right)\right]\left(H_{2}-H_{1}\right)
$$

51 The following comments are based on former tax legislation up to 1995, excluding the tax relief on loan interest (which was limited to three years) up to the end of 1994 as well as the special assistance measures in eastern Germany. The system of assistance for residential property that was reformed by the "Owneroccupied Housing Allowance Act" of January 1, 1996 has not been taken into consideration.

52 A further benefit of price stability is the prevention of the "front loading" problem. This liquidity effect makes the acquisition of residential property more difficult since - given positive inflation - the real debt service is highest at the start of the period and later decreases; see the Report of the Expert Commission on Housing Policy (Bericht der Expertenkommission zur Wohnungspolitik) (1994, p. 162 ff.). Given price stability, the real burden would, by contrast, be equally high throughout the period of the mortgage. Croushore (1992) estimates the benefit of this effect alone - assuming a reduction of inflation by 2 percentage points - to be between $0.06 \%$ and $0.12 \%$ of GDP. 
where $\mathrm{H}$ is the demand for owner-occupied housing and $\mathrm{R}$ represents the user costs per D-Mark of invested capital.

\subsubsection{The price and quantity component}

In the absence of taxes and inflation, the implicit rental costs of residential property would amount to

$$
R_{0}=r_{0}+m+\delta
$$

where $m+\delta$ is the sum of maintenance costs and depreciations per D-Mark of employed capital, which we put at $4 \%$. Given a real gross rate of return in the enterprise sector of $r_{0}=10.8 \%$, the user costs amount to $R_{0}=14.8 \%$. By contrast, under the present tax legislation the following calculation is relevant for a married couple given inflation: 53

$$
R_{2}=\mu i_{m}+(1-\mu)\left(r_{2}+\pi\right)+(m+\delta)-\tau ' h-\pi
$$

In this, $\mu$ designates the share of the mortgage debt in the value of the house, $i_{m}$ the nominal mortgage rate and $h$ the tax concession per D-Mark of invested capital. Accordingly, the annual user costs of owner-occupied housing are the sum of the (non-tax deductible) interest payments on the mortgage debts, the opportunity costs of the invested capital as well as the maintenance and depreciation costs. The tax saving due to the possibilities of deduction for tax purposes and the inflation-induced increase in value of the property are to be counted against this.

Under the previous form of section 10 of the Income Tax Code, $6 \%$ of the (maximum DM 330,000) acquisition costs of owner-occupied dwellings (which were completed in 1992 or later) may be deducted for tax purpose for an initial

53 Owner-occupied houses are, in principle, also subject to general (net) wealth tax. Because of the low values to be assessed and the nominal value of the mortgage debts to be counted against them, however, very little wealth tax or none at all is due. Profits from sales are basically negligible in terms of income tax legislation. 
period of four years and $5 \%$ for a further four years. ${ }^{54}$ Over eight years this assistance adds up DM 145,200. In addition, the home buyers' child benefit of DM 1,000 per child is deducted from liable tax. In the case of two children, this produces an amount of DM 16,000, which - given a tax rate of $\tau^{*}=37.6 \%$ corresponds to a gross deductible amount of around DM 42,600. In total, this produces a reduction in the tax base of DM 187,800 for the entire period in which assistance is granted. If the average acquisition costs are assumed to be DM $373,000^{55}$, this correponds to around $50 \%$ of the acquisition costs. Both marriage partners can make use of this assistance once. This is taken into account by halving the useful economic life of the property to 25 years. Spread over that period, the tax-deductible amount is $h=50 / 25=2 \%$ p.a. of the acquisition costs. Given a share of borrowing in capital spending on housing construction of $\mu=60 \%$ and a nominal annual mortgage rate of $8.5 \%$ (at $2 \%$ inflation), (3.24) results in $R_{2}=0.6^{\star} 8.5+(1-0.6)^{\star}(4.24+2)-0.376^{\star} 2+4-2=8.85 \%$.

Assuming that the simple Fisher relationship $\left(\mathrm{di}_{\mathrm{m}} / \mathrm{d} \pi=1\right)$ applies to the mortgage rate, and also considering the fact that according to (3.14) $\mathrm{dr}_{2} / \mathrm{d} \pi=-\omega$, it follows from (3.24) that $\left.d_{2} / d \pi=-\omega\right)(1-\mu)$. This assumes that $h$ is independent of the inflation rate. Given a lack of inflation, the user costs would hence rise to

$$
R_{1}=R_{2}+\pi \omega(1-\mu)
$$

Since $\omega=0.31$ was calculated above, it follows that $R_{1}=8.84+2{ }^{*} 0.31 *(1-0.6)=$ $9.09 \%$, i.e. the elimination of an inflation rate of $2 \%$ would increase the user costs of owner-occupied housing by 0.24 percentage points. The welfare effect (3.22) becomes $\mathrm{G}_{\mathrm{H} 1}=0.0583\left(\mathrm{H}_{2}-\mathrm{H}_{\mathrm{t}}\right)$. The increase in user costs which are distorted downwards by inflation results in a decline in the demand for housing, which leads to a corresponding reduction of capital misallocation. We approximate this quantity effect by

54 Since 1991, an income limit for a single/couple of DM 120,000/240,000 (relative to total sum of income) has applied to basic assistance and home buyers' child benefit.

55 Between 1991 and 1995, the pure construction costs amounted to an average of DM 2,500/ $\mathrm{m}^{2}$. This gives construction costs of around DM 305,000, assuming an average floor area of $122 \mathrm{~m}^{2}$. Furthermore, DM 50,000 in real estate costs are added to this, assuming that a property has an area of $200 \mathrm{~m}^{2}$ and a real estate price of DM $250 / \mathrm{m}^{2}$. Finally, assuming ancillary costs of around $5 \%$ of the acquisition costs results in the above-mentioned value of DM 373,000. 


$$
H_{2}-H_{1}=\frac{R_{1}-R_{2}}{R_{2}} H_{2} \varepsilon_{H R}
$$

where $\varepsilon_{H R}$ is the compensated interest rate elasticity of capital spending on housing construction. Döpke (1996) estimates a long-term value of 0.14 for the uncompensated interest rate elasticity. This corresponds to a compensated elasticity of around $\varepsilon_{\mathrm{HR}}=0.25 .{ }^{56} \mathrm{~A}$ ratio of 1.7 between the value of the owneroccupied housing stock and GDP thus gives $\mathrm{H}_{2}-\mathrm{H}_{1}=1.20 \%$ of GDP. In conjunction with the price effect, the direct benefit of price stability with owneroccupied housing is $\mathrm{G}_{\mathrm{H} 1}=0.07 \%$ of GDP.

\subsubsection{The indirect revenue effect}

The indirect revenue effect is defined as

$$
\mathrm{G}_{\mathrm{H} 2}=\lambda_{\mathrm{C}}\left(\mathrm{H}_{1}-\mathrm{H}_{2}\right) \mathrm{r}_{0} \Theta
$$

A fall in demand for owner-occupied housing of $1.20 \%$ of GDP was produced by (3.26). The capital stock in the enterprise sector increases by the same amount and generates a gross rate of return of $r_{0}=10.8 \%$ and a net yield (without inflation) of $r_{1}=4.87 \%$. This corresponds to an effective average rate of taxation of $\Theta=55 \%$, i.e. $\mathrm{G}_{\mathrm{H} 2}=1.20^{\star} 0.108^{\star} 0.55=0.07 \%$ of GDP. If the deadweight loss per D-Mark of tax revenue calculated above is likewise put at $\lambda_{C}=0.34$ here, a net benefit is produced on balance (given price stability) of

$$
G_{H}=G_{H 1}+G_{H 2}=0.07+0.34 * 0.07=0.09 \% \text { of } G D P
$$

56 The relationship $\varepsilon=\eta+\Xi^{*}(\mathrm{H} / \mathrm{Y})$ applies between the compensated $(\varepsilon)$ and uncompensated ( $\eta$ ) elasticity, where $\Xi$ is the income elasticity of the capital spending on housing construction and $H / Y$ the ratio of capital spending on housing construction to disposable income. With the income elasticity of 1.26 estimated by Döpke (1996) and a ratio of capital spending on housing construction to disposable income of $10 \%$, this gives $\varepsilon=0.14+1.26 * 0.10 \cong 0.25$ for the compensated elasticity. 


\subsection{Money demand and seigniorage}

\subsubsection{The direct welfare effect}

Inflation increases the alternative costs of holding non-interest-bearing money balances and lowers the real demand for money below its optimal level. Since the real costs of an increase in the money stock are virtually nil, the optimal money stock, according to Friedman (1969), is that in which the opportunity costs of cash holdings are zero, i.e. $r\left(\pi^{*}\right)+\pi^{*}=0.57$

With the current system of taxation and given $2 \%$ inflation, the opportunity costs of cash holdings are $r_{2}+\pi=4.24+2.0=6.24 \%$. Given a zero inflation rate, these costs fall to $r_{1}=4.87 \%$. A Harberger analysis of the money demand produces the following trapezoid as the welfare gain due to a lowering of the inflation rate from effectively $2 \%$ to zero

$$
G_{M 1}=\left[\left(r_{1}-0\right)+\frac{1}{2}\left(r_{2}+\pi-r_{1}\right)\right]\left(M_{1}-M_{2}\right)
$$

i.e. $\mathrm{G}_{\mathrm{M} 1}=0.0556\left(\mathrm{M}_{1}-\mathrm{M}_{2}\right)$. The change in the money demand can be approximated by

$$
M_{1}-M_{2}=\frac{r_{2}+\pi-r_{1}}{r_{2}+\pi} \varepsilon_{M i} M_{2}
$$

According to our estimations, the interest rate elasticity of the demand for money (currency in circulation and required reserves), is $\varepsilon_{\mathrm{Mi}}=0.25$ in absolute value. Given a $9 \%$ share of these monetary components in GDP, it follows that $M_{1}-M_{2}=$ $0.50 \%$ of GDP. The product of the price and the quantity effect gives the direct

57 The value $r_{1}=4.87 \%$ has been determined for the real return given a zero inflation rate. Assuming for the sake of simplicity that the real yield is a linear function of the inflation rate, to which $\mathrm{dr} / \mathrm{d} \pi=-\omega$ applies, the optimal inflation rate according to Friedman is produccd as the solution of $r_{1}-0.31 \pi^{*}+\pi^{*}=0$, i.e. $\pi^{*}$ $=-7 \%$. If there are no lump-sum taxes, it is theoretically possible. howcver, that the inflation rate is positive as part of an optimal tax mix provided that money is regarded as an end good and not as an intermediate good. See also the papers by Phelps (1973) and Chari et al. (1991). 
welfare gain of price stability in the money demand; it amounts to just $\mathrm{G}_{\mathrm{M} 1}=$ $0.03 \%$ of GDP.

\subsubsection{The indirect revenue effect}

The indirect revenue effect of a reduced money demand is made up of three components. Firstly, the reduction of the "inflation tax" to real money balances (M) leads to a loss of monetary seigniorage. This implies a welfare loss since other distorting taxes have to be increased. The (active) seigniorage to the amount of 58

$$
S=\pi M
$$

reacts to changes in the inflation rate in accordance with $d S / d \pi=M+\pi(d M / d \pi)$. After some transformations using $d\left(r_{2}+\pi\right) / d \pi=1-\omega$, this may be written as

$$
d S=\left[1-\varepsilon_{M i}(1-\omega) \frac{\pi}{r_{2}+\pi}\right] M \pi
$$

Assuming a ratio of the money balances (currency in circulation and minimum reserves) to GDP of $9 \%$ and an interest rate elasticity of the money demand in absolute terms of $\varepsilon_{\mathrm{Mi}}=0.25$, the loss of seigniorage if there is price stability comes to $\mathrm{dS}=0.17 \%$ of GDP.

Secondly, an income effect results from the fact that less capital and more real money balances are held if there is price stability. The value $M_{1}-M_{2}=0.50 \%$ of GDP has been determined above for the rise in the money demand. In the enterprise sector this capital earns a gross return of $r_{0}=10.8 \%$ and is subject (given price stability) to taxation at $\Theta=55 \%$. The loss of income is thus

$$
\mathrm{dK}=\left(\mathrm{M}_{1}-\mathrm{M}_{2}\right) \mathrm{r}_{0} \Theta
$$

i.e. $\mathrm{dK}=0.03 \%$ of GDP.

58 Seigniorage also arises in a growing economy independently of the rate of inflation (passive scigniorage). 
Thirdly, the Government is in a position to reduce interest-bearing debt instruments to the amount of the increased cash holdings. Although this is a oneoff effect, it permanently reduces the Government's debt service by

$$
\mathrm{dB}=\mathrm{r}_{\mathrm{ng}}\left(\mathrm{M}_{1}-\mathrm{M}_{2}\right)
$$

where

$$
r_{\mathrm{ng}}=\left(1-\tau^{\prime}\right) \gamma-\pi
$$

is the real rate of interest on the public debt. Assuming that the ratio of the debt service to the public debt is $\gamma=7.8 \%$, and given a rate of taxation of $\tau^{\imath}=37.6 \%$, there is a real interest rate of $r_{\mathrm{ng}}=2.87 \%$. The income effect thus comes to $\mathrm{dB}=$ $0.01 \%$ of GDP. The total loss of government income if there is price stability is therefore

$$
\mathrm{G}_{\mathrm{M} 2}=-\mathrm{dS}-\mathrm{dK}+\mathrm{dB}
$$

i.e. $\mathrm{G}_{\mathrm{M} 2}=-0.19 \%$ of GDP. Using the same shadow price of taxation as before yields a small negative benefit of money demand under price stability:

$$
G_{M}=G_{M 1}+G_{M 2}=0.03+0.34^{*}(-0.19)=-0.04 \% \text { of GDP. }
$$

\subsection{Government debt service}

This section considers the welfare effect which results from the fact that higher real rates of interest also increase the real costs of the Government's debt service. A fully anticipated inflation leaves the real gross interest rate on the public debt unchanged, whereas the inflation premium is subject to income tax. A lower inflation rate hence does not reduce the pre-tax cost of the debt service, i.e. it does not produce a direct advantage, but does reduce the tax revenue accruing from the (eligible) interest rate payments on the public debt. This requires a compensatory increase of other taxes.

The starting point for quantifying this effect is the following budget equation for the change in the level of debt (D): 


$$
\Delta \mathrm{D}=\mathrm{G}-\mathrm{T}+\left(\mathrm{r}_{\mathrm{g}}+\pi\right)\left(1-\tau^{\prime}\right) \mathrm{D}
$$

where $r_{g}$ is the real gross interest rate on the public debt and $\tau^{\prime}$ is the marginal rate of taxation. In equilibrium the public debt grows at the same rate as nominal GDP, i.e. $\Delta D=D(n+g+\pi)$. Combining this equilibrium condition with the above budget equation produces the following expression for the tax revenue:

$$
T=\left[\left(1-\tau^{\prime}\right)\left(r_{g}+\pi\right)-(n+g+\pi)\right] D+G
$$

Differentiation of this budget constraint with respect to the inflation rate gives the reaction of tax revenue if there is a change in the inflation rate:

$$
d T=-\tau^{\prime} D d \pi
$$

Given a Government debt of $D=48 \%$ of GDP on an average of the years 1991$95, d \pi=2$ p.p. produces a change of $d T=0.36 \%$ of GDP. This fall in tax revenue resulting from the elimination of inflation must be offset by compensatory tax increases, which gives rise to a (negative) benefit:

$$
G_{D}=0.34^{\star}(-0.36)=-0.12 \% \text { of GDP }
$$

\subsection{Overall benefit of price stability}

The benefits of a zero inflation rate from the intertemporal allocation of consumption $\left(G_{C}\right)$, the demand for owner-occupied housing $\left(G_{H}\right)$, the demand for money $\left(G_{M}\right)$ and the Government's debt service $\left(G_{D}\right)$ are combined in Table 3.1: 
Table 3.1: The benefits of price stability

Reduction of the effective inflation rate from $2 \%$ to $0 \%$ (as \% of GDP)

\begin{tabular}{|l|c|c|c|c|}
\hline \multirow{2}{*}{ Item } & \multicolumn{3}{|c|}{ Welfare effect } & $\begin{array}{c}\text { Memo } \\
\text { item: }\end{array}$ \\
\cline { 2 - 5 } Consumption timing & direct & indirect & overall & $\begin{array}{c}\text { United } \\
\text { States }\end{array}$ \\
Housing demand & 1.95 & -0.47 & 1.48 & 0.95 \\
Money demand & 0.07 & 0.02 & 0.09 & 0.22 \\
Debt Service & 0.03 & -0.06 & -0.04 & -0.03 \\
\hline Overall benefit & - & -0.12 & -0.12 & -0.10 \\
\hline Memo item: United States & 2.04 & -0.63 & 1.41 & 1.04 \\
\hline
\end{tabular}

Accordingly, the reduction of an (anticipated, equilibrium and effective) inflation rate from 2 percent to zero results in a benefit of $1.41 \%$ of GDP year by year. This benefit is primarily the outcome of preventing inflation-induced distortions in the intertemporal allocation of consumption and saving (1.48\% of GDP). The correction of the distortions in the demand for owner-occupied housing makes a net contribution amounting to $0.09 \%$ of GDP. The slight benefit in the case of the money demand is overcompensated by the associated shortfalls in government income, resulting on balance in costs amounting to $0.04 \%$ of GDP. The lack of the alleviating financing effect of inflation in the servicing of the public debt leads by itself to further costs, which are estimated at $0.12 \%$ of GDP. Just under onethird of the direct welfare gains amounting to $2.04 \%$ of GDP is used up again by indirect revenue shortfalls. 
Figure 3.1: Benefit of price stability

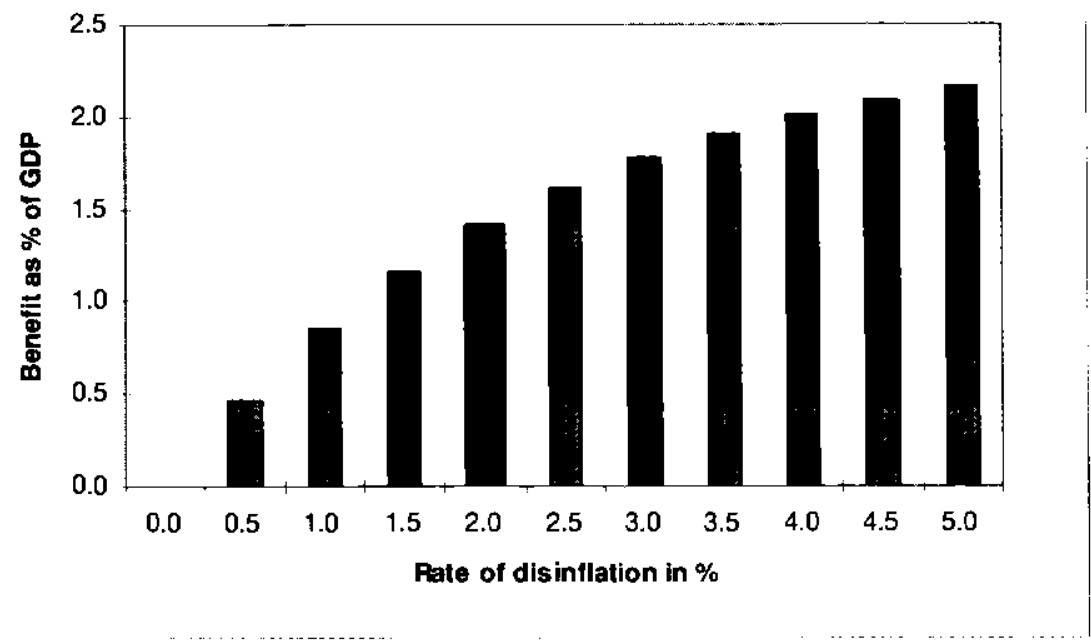

During the years 1991 to 1995 the statistically measured inflation rate in Germany came to an average of $3.3 \%$. On account of the lack of precision in statistical measuring, it is not possible to state beyond doubt whether this corresponds to an effective inflation rate of $2 \%$. There is hence some amount of uncertainty regarding the actual size of the "disinflation potential". As Chart 3.1 shows, the benefit of price stability is a non-linear function of the size of reduction in inflation. Assuming a reduction in inflation of 3 percentage points (which would then roughly correspond to a measured inflation rate of zero), rather than of 2 percentage points, the benefit increases from $1.41 \%$ to $1.78 \%$ of GDP. Conversely, a reduction in the inflation rate by only 1 percentage point would still produce a sizeable benefit of $0.85 \%$ of GDP. By way of approximation, the relationship between the size of the reduction in inflation $(\pi)$ and the benefit as a percentage of GDP (G) may be expressed by

$$
\mathrm{G}=\pi^{\zeta}, \quad \zeta>0
$$

where $\zeta=1 / 2$ describes this relationship quite well.

Comparing the results for Germany with Feldstein's for the United States reveals greater differences, above all, in terms of the intertemporal allocation of 
consumption. At $1.95 \%$ of GDP (according to our calculation), the direct welfare gain in this component is almost twice as great as Feldstein's at $1.02 \%$. In order to explain this difference, the direct benefit of price stability in the consumption allocation has been broken down into the product of four factors in the following table 3.2: the relative price effect (RPE), the interest rate elasticity of consumption, the relative savings of the young generation and the share of private saving in GDP. As this shows, the differences in the first three of those effects are comparatively small and they mutually compensate each other. The greater benefit of price stability in our calculation hence ultimately rests on the fact that the saving ratio (as \% of GDP) is almost twice as high in Germany as it is in the United States.

Table 3.2: Comparison of results with the United States

\begin{tabular}{|c|c|c|c|c|c|c|}
\hline \multirow[t]{2}{*}{ Country } & $\begin{array}{l}\text { Relative } \\
\text { price effect }\end{array}$ & $\begin{array}{c}\text { Interest rate } \\
\text { elasticity }\end{array}$ & $\begin{array}{c}\text { Savings of the } \\
\text { young } \\
\text { generation }\end{array}$ & $\begin{array}{c}\text { Saving ratio } \\
\text { in } \%\end{array}$ & $=$ & $\begin{array}{c}\text { Direct } \\
\text { benefit as } \% \text { of } \\
\text { GDP }\end{array}$ \\
\hline & RPE $^{-1}$ & $\left|E_{\mathrm{C} \rho}\right|$ & $S_{y} / S_{N}$ & $\mathrm{~S}_{N} / \mathrm{GDP}$ & $=$ & $\mathrm{G}_{\mathrm{C} 1}$ \\
\hline \multirow{2}{*}{$\begin{array}{l}\text { Germany (GY) } \\
\text { United States (US) }\end{array}$} & 0.109 & 0.854 & 2.251 & 9.30 & $=$ & 1.95 \\
\hline & 0.092 & 1.230 & 1.800 & 5.00 & $=$ & 1.02 \\
\hline Ratio (GY/US) & 1.19 & 0.69 & 1.25 & 1.86 & $=$ & 1.91 \\
\hline
\end{tabular}

The higher saving ratio in Germany also largely explains the greater (negative) indirect income effect in our calculation. Putting the saving ratio in our calculation at $5 \%$ for Germany, too, would produce a direct benefit in consumption allocation of $1.26 \%$ of GDP (compared with $1.02 \%$ for the United States) and an indirect income effect of $-0.22 \%(-0.10 \%)$. Despite all the other differences in the system of taxation and in the structural and behavioural parameters in the two economies, the overall benefit of a reduction in the inflation rate by 2 percentage points - given matching saving ratios - would be almost equally as high, at $0.94 \%(1.02 \%)$ of GDP, as for the United States. Hence, it is the high savings rate in Germany, 
coupled with capital income taxes, which explains the large costs of even moderate rates of inflation.

\subsection{The risks: some sensitivity calculations}

Our calculations of the scale of the benefit due to price stability rely on a number of simplifying assumptions. Furthermore, some of the assumed quantitative values for the structural and behavioural parameters of the German economy are attended by considerable uncertainties. The table in Appendix $\mathbf{D}$ contains an overview of all parametric assumptions (benchmark values) and a comparison with the coefficients assumed by Feldstein for the United States.

In order to obtain some initial points of reference for the sensitivity of the calculations in terms of the assumptions that have been made, we have calculated each coefficient with alternative lower and upper values deviating from the benchmark. The range of these values was chosen to correspond to what we felt subjectively to be roughly two standard deviations.59 As the results of these calculations show in Appendix E, varying the coefficients changes the overall benefit only comparatively little, most results remain within the range of $1.41 \%$ $+/-0.10 \%$ of GDP. The benefit of price stability which has been estimated thus appears to be quite robust in terms of the parametric assumptions that have been made.

An exception to this is the length of the discounting period. If the period is reduced (increased) from $T=27$ to $T=24(30)$ years, the benefit of price stability falls (rises) to 1.30 ( 1.51$) \%$ of GDP. One very important parameter is also the average rate of taxation on distributed profits $(t=60.7 \%)$, a 3 percentage point reduction, which lowers the overall benefit to $1.31 \%$ of GDP, whereas an increase by the same amount raises the overall benefit of disinflation to $1.52 \%$. Besides this, the marginal rate of taxation $\left(\tau^{*}=37.6 \%\right)$ has an appreciable influence.

59 For a normally distributed random variable, the stated interval includes the actual value with a probability 
In addition, the calculations react quite sensitively to the assumption concerning the interest rate elasticity of savings, for which a benchmark value of $\eta_{S_{r}}=0.25$ was determined (see Appendix C). A lowering of this elasticity to 0.10 reduces the benefit to $1.11 \%$ of GDP, whereas an increase to 0.40 (i.e. the benchmark value used by Feldstein) increases the benefit to $1.74 \% .60$

The shadow price of taxation for calculating the indirect revenue effects was set by Feldstein at the benchmark value $\lambda=0.4$ and the alternative value 1 . As explained above, this parameter is not set exogenously in our calculations, but is instead determined model-endogenously as the shadow price of capital income taxation with the value $\lambda=0.34$.

Deterministic parameter variations, in which all the other input values are kept constant, can give only an incomplete description of the uncertainties contained in a model calculation of this kind. For that reason, we have also used a Monte Carlo simulation to assess the variability of the benefit of price stability. In doing this, we regard all 23 parameters as independently normally distributed random variables.61 The mean values of this distribution are the benchmark values used in our calculation. The difference between the lower (or upper) parameter value shown in Appendix E and the benchmark value was set as the (subjective) standard deviation in all cases. As mentioned above, we assume that there is a roughly 0.68 probability of the actual parameter value being within the stated interval. We have taken a random sample from each of the 23 distributions and recalculated the benefit of price stability. This operation was repeated 10,000 times.

Table 3.3 shows the results of these simulation exercises. At $1.39 \%$ of GDP, the arithmetical mean of the benefit of price stability is very close to the deterministic value 1.41 . The simulated standard deviation amounts to $0.47 \%$ of GDP. The median of the distribution of the overall benefit is $1.34 \%$ of GDP. This means (see

60 This sensitivity to the interest rate elasticity of savings is likewise revealed in the calculations made by Feldstein, which show the overall benefit $(0.65 ; 1.04 ; 1.62)$ for alternative values of the interest rate elasticity $(0 ; 0.4 ; 1)$.

61 The assumption of independence is undoubtedly a grcat simplification. An empirically grounded estimation of the correlation structures between the structural parameters and the behavioural coefficients womld an hevend the sonme of thic study however 
also Figure 3.2) that the distribution of the benefit is positively skewed, which is likewise expressed in the positive Pearson measure of skewness of 0.30 .

Table 3.3: The benefits of price stability ${ }^{+}$

(as \% of GDP)

\begin{tabular}{|l|c|c|c|c|}
\hline \multicolumn{1}{|c|}{ Item } & $\begin{array}{l}\text { Mean } \\
\text { value }\end{array}$ & $\begin{array}{l}\text { Standard } \\
\text { deviation }\end{array}$ & Median & Skewness*) \\
\hline Consumption timing & $\mathbf{1 . 4 4}$ & 0.490 & $\mathbf{1 . 3 9}$ & 0.30 \\
Housing demand & $\mathbf{0 . 1 0}$ & 0.065 & $\mathbf{0 . 0 9}$ & 0.62 \\
Money demand & -0.03 & 0.023 & -0.03 & -0.22 \\
Debt service & -0.12 & 0.044 & -0.12 & -0.28 \\
\hline Overall benefit & $\mathbf{1 . 3 9}$ & 0.473 & 1.34 & 0.30 \\
\hline
\end{tabular}

+) Based on 10,000 stochastic simulations.

*) Pearson's measure of skewness: $3^{*}$ (arithmetical mean - median)/standard deviation.

According to the simulation calculations, the probability of an overall benefit of less than $1 \%$ of GDP is 0.21 . By contrast, the probability of the benefit being greater than the break-even point of $\mathrm{G}=0.28 \%$ of GDP (which was established in Chapter 2) is 0.998 . 
Figure 3.2: Frequency distribution of benefits

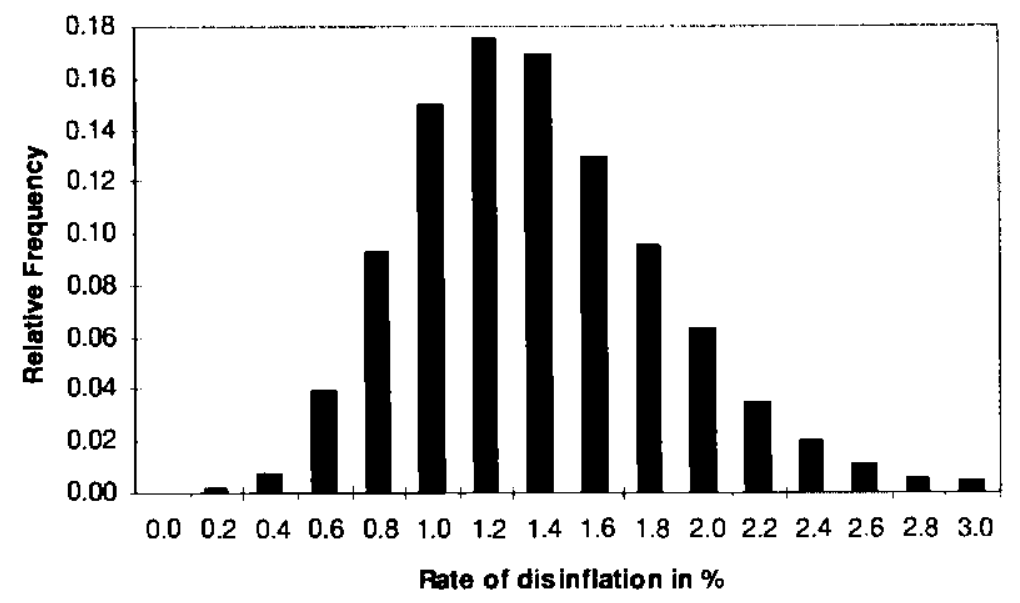

\subsection{On the optimal rate of disinflation}

We have assumed hitherto that the rate of inflation is reduced by 2 percentage points. In view of the determined costs and benefits, it remains questionable whether this is the optimal strategy, however. This requires an additional test criterion. Howitt (1990, p. 104), from a welfare-economic point of view, postulates the following rule in order to assess which (dis)inflation rate a central bank should aim for (Howitt's Rule): 62

"In order to estimate the optimal target rate of inflation, one must somehow balance the gains from reducing inflation against the costs of doing so. The reduction in inflation should continue as long as the present discounted value of the benefits to society from a further small reduction exceeds the present discounted value of the cost. The optimal target rate is the rate at which the benefit of further reduction just equals the cost of raising unemployment by the required amount above the natural rate."

\footnotetext{
${ }^{62}$ Howitt's Rule is discussed in detail by Thornton (1996).
} 
As the preceding comments have shown, both the benefits (G) and the costs $(C)$ are regarded as (non-linear) functions of the rate of disinflation $(\pi)$ (see (2.11), (3.39) and Figure 3.3).

As a function of the constant discounting factor $\rho$ (see section 2.3), the net benefit (g) of disinflation may be expressed as

$$
g(\pi)=G(\pi)-\rho C(\pi)=\pi^{\zeta}-\rho \sigma \pi^{1+\varphi}
$$

In accordance with Howitt's Rule, the optimal disinflation rate ( $\left.\pi^{*}\right)$ must fulfil the necessary condition $\partial g / \partial \pi=0$, resulting in

$$
\pi^{*}=\left(\frac{1}{\rho \sigma} \frac{\zeta}{1+\varphi}\right)^{1+\varphi-\zeta}
$$

The higher the discounting rate and the higher the sacrifice ratio are, the lower the optimal disinflation rate is. Assuming as before $\zeta=\varphi=1 / 2, \rho=2.5 \%$ and $\sigma=4$, the optimal disinflation rate is $\pi^{\star}=3.3 \%$ (see Figure 3.4). The empirical data used in the estimate reflect the average conditions in the period 1991-95 when the statistically measured average inflation rate was $3.3 \%$. Bearing this in mind, the result achieved suggests the conclusion that it would be optimal to aim at a zero inflation rate or stability of the measured price level. ${ }^{63}$ The result obtained for the optimal inflation rate in accordance with (3.41) depends to a considerable extent, however, on the choice of the parameters included in it and, for that reason, should not be overvalued. Additionally, there are uncertainties and risks both in quantifying the disinflation costs and (as the sensitivity analyses have shown) in quantifying the benefits which suggest a cautious interpretation of the results.

63 As Scarth (1990) has shown, a goal of this kind would be both transparent and credible. 

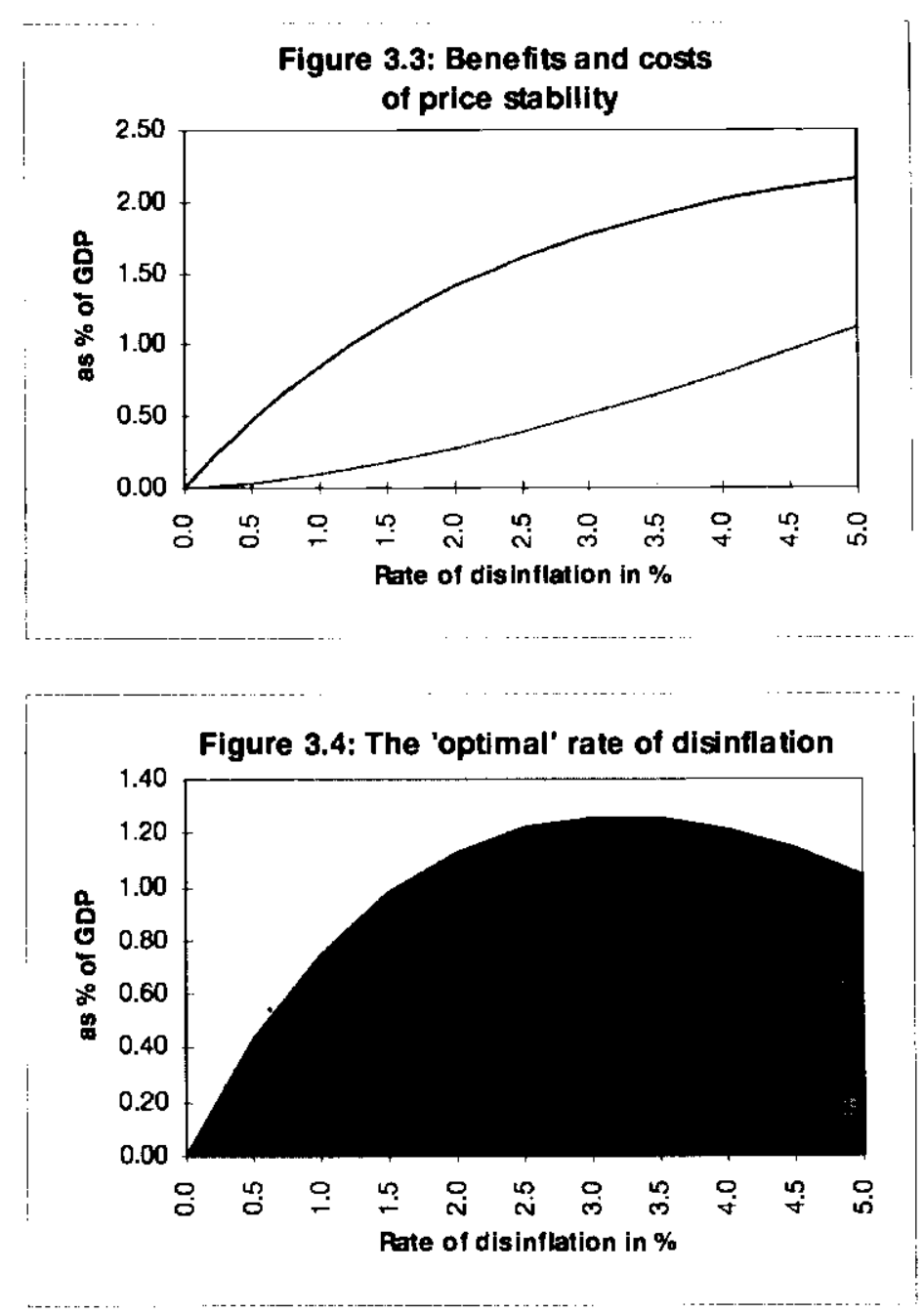
"If there is anything in the world which ought to be stable it is money, the measure of everything which enters the channels of trade."

Francois Le Blanc, Traité historique des monnayes de

France, Paris, 1690, quoted after Einaudi, 1953, p. 233.

\section{Summary and conclusions}

In the run-up to European monetary union and the discussion to be held on the monetary policy strategy of a future European Central Bank, Issing (1996a, p. 309) writes, "The current large measure of consensus is not a guarantee, however, that the pendulum will not swing back at some point in the future... The risk of inflation is not dead simply because the statistics show price stability at present. It will have been really conquered only when it has disappeared once and for all from the range of attractive available policy options."

In that respect, this study has confirmed for Germany what Feldstein discovered for the United States: inflation is anything but an attractive option. The interaction of even moderate rates of inflation with the existing system of taxation results in a significant loss of welfare. The change from an equilibrium 'true' inflation rate of $2 \%$ (which may correspond to a measured rate of $3 \%$ ) to a rate of zero brings permanent welfare gains, equivalent to $1.4 \%$ of GDP year for year. The deadweight loss of two percent inflation is so great because Germany has a high savings rate, capital income is taxed heavily, and the tax system is not indexed. Inflation intensifies the distortions of taxation on capital income. For that reason the welfare gains of price stability should not be measured by a "Harberger triangle“, but by a „Feldstein trapezoid“. Even if we regard the output losses (in the form of a temporary Okun gap) during disinflation as far away from being negligible, there are, in our opinion, no convincing arguments for a moderate inflation being superior to price stability.

In the years 1991 to 1995 , the base period of our calculations, the average measured rate of inflation turned out to be $3.3 \%$ p.a. In 1996 the rate of inflation was $1.5 \%$. Considering the sustained economic problems of the new Länder in 
east Germany and the difficult labor market situation, the question may be asked whether this policy of disinflation by about 2 percentage points was justified or whether the Bundesbank should have executed a more expansionary monetary policy in order to stabilize the inflation rate at $3.3 \%$ ?

According to our calculations, the disinflation by almost 2 percentage points was well justified, provided one is prepared to look not only at the short lived costs of disinflation but also at the more long term gains of price stability. This is a powerful argument for putting monetary policy into the hands of an independent and forward-looking institution with a long time horizon. An independent central bank with the primary goal of price stability is able to invest into the public good called price stability even if the starting costs exceed the first round benefits, as it is usually the case for long-lived investments. Besides this, it should'nt be forgotten that the sacrifice ratio hinges on the degree of nominal rigidity, which can be influenced to some extent by carefully choosing the timing, speed and policy-mix of disinflation. The following menu of choice summarizes the main results of our study.

\section{Table 4.1: The menu of choice}

Costs and benefits as \% of GDP

\begin{tabular}{|r|r|r|r|r|r|r|}
\hline Initial measured rate of inflation & 3.3 & 3.3 & 3.3 & 3.3 & 3.3 & 3.3 \\
\hline Rate of disinflation & 0.0 & 1.0 & 2.0 & 3.3 & 4.0 & 5.0 \\
\hline Final measured rate of inflation & 3.3 & 2.3 & 1.3 & 0.0 & -0.7 & -1.7 \\
\hline Permanent benefits & 0.00 & 0.85 & 1.41 & 1.86 & 2.01 & 2.24 \\
\hline Annualized costs & & & & & & \\
\hline & 0.00 & 0.10 & 0.28 & 0.60 & 0.80 & 1.12 \\
\hline Benefits minus costs & & & & & & \\
\hline Annual loss in welfare: & 0.00 & 0.75 & 1.13 & 1.26 & 1.21 & 1.12 \\
\hline
\end{tabular}

*) Average rate of inflation between 1991 and 1995 
Stabilizing the rate of inflation at $3.3 \%$ would have avoided any costs of disinflation, but there would have been no gains either. Compared to the optimal strategy, the policy of preserving the status quo achieved at that time would have incurred a permanent annual welfare loss of roughly $1.3 \%$ of GDP. A modest disinflation by 1 percentage point already would have reduced the unexploited gains to $0.5 \%$ of GDP. The actual amount of disinflation by almost 2 percentage points exploits almost all potential gains, provided present rate of inflation will be sustained. More disinflation (to bring the measured rate down to zero) would produce only small additional gains. On the other hand, as table 4.1 shows, overshooting the optimal rate of disinflation is associated with relatively small welfare losses. However, one should keep in mind that there are other costs and benefits of disinflation, not investigated in this paper. A too low, i.e. negative, inflation rate may, for example, destabilize the international financial markets and cause a range of other adjustment problems.

Having made these caveats, we conclude our study as follows:

Importance: Inflation, even at moderate rates of 2 or $3 \%$ p.a., is a very costly économic policy option.

Asymmetry: The welfare loss of a too high inflation rate is large, the welfare loss of a too small inflation rate appears to be small.

Robustness: It does not matter much whether monetary policy aims at price stability in terms of the measured or the 'true' rate of inflation. This decision should be based on criteria like transparency, clarity and - above all - credibility.

At the outset we asked the question of whether the benefit of price stability justifies the costs of disinflation. To this we can now give an unequivocal short answer: No inflation is better than low inflation! In fact, our results clearly indicate that the aim of price stability should receive priority. Tobin's often-quoted comment (1977, p. 467) that "It takes a heap of Harberger Triangles to fill an Okun Gap..." hence needs to be amended. In brief - and to extend the metaphor - it should go on to read, "... but it needs only one single Feldstein Trapezoid to do it". 


\section{References:}

Akerlof, G.A., W.T. Dickens and G.L. Perry (1996): „The Macroeconomics of Low Inflation“, Brookings Papers on Economic Activity, No. 1, pp. 1 - 76.

Attanasio, O.P. and G. Weber (1995): „On the Aggregation of Euler Equations for Consumption in Simple Overlapping-Generations Models“, Economica, Vol. 62, pp. 565-76.

Auerbach, A. (1978): „Appendix: The Effect of Inflation on the Tax Value of Depreciation", Appendix in: M. Feldstein, J. Green and E. Sheshinski, Inflation and Taxes in a Growing Economy with Debt and Equity Finance, Journal of Political Economy, Part 2, pp. S68-S70.

Bailey, M. (1956): „The Welfare Costs of Inflationary Finance“, Journal of Political Economy, Vol. 64, pp. 93-110.

Ball, L. (1994): „What Determines the Sacrifice Ratio?“, in: N.G. Mankiw (ed.), Monetary Policy, pp. 155-93, Chicago: The University of Chicago Press.

Barro, R.J. (1995): "Inflation and Economic Growth“, Bank of England Quarterly Bulletin, Vol. 35, No. 2, pp. 166-75.

Beaudry, T. and E. van Wincoop (1996): "The Intertemporal Elasticity of Substitution: An Exploration Using a US Panel of State Data“, Economica, Vol. 63, pp. 495-512.

Black, R., T. Macklem and St. Poloz (1994): „Non-Superneutralities and Some Benefits of Disinflation: A Quantitative General-Equilibrium Analysis", in: Bank of Canada (ed.), Economic Behaviour and Policy Choice Under Price Stability, Proceedings of a Conference held at the Bank of Canada, October 1993, Ottawa.

Blanchard, O.J. and S. Fischer (1989): Lectures on Macroeconomics, Cambridge, Mass.: The MIT-Press.

Chari, V.V., L.J. Christiano and P.J. Kehoe (1991): „Optimal Fiscal and Monetary Policy: Some Recent Results“, Journal of Money, Credit, and Banking, Vol. 23, No. 3, pp. 519-39.

Croushore, D. (1992): „What Are the Costs of Disinflation?", Business Review, Federal Reserve Bank of Philadelphia, May/June, pp. 3-16.

Darby, M. (1975): „The Financial and Tax Effects of Monetary Policy on Interest Rates“, Economic Inquiry, Vol. 13, pp. 266-76.

Deutsche Bundesbank (1994a): Macroeconometric Model of the German Economy".

Deutsche Bundesbank (1994b): „Verhältniszahlen aus Jahresabschlüssen westdeutscher Unternehmen für 1990". 
Deutsche Bundesbank (1996a): „Ergebnisse der gesamtwirtschaftlichen Finanzierungsrechnung für Deutschland 1990-1995“, Statistische Sonderveröffentlichung No. 4.

Deutsche Bundesbank (1996b): „Die gesamtwirtschaftlichen Finanzierungsströme in Deutschland in 1995“, Monatsbericht, Mai, pp. 25-47.

Deutsche Bundesbank (1996c): „Makro-ökonometrisches Mehr-Länder-Modell", Sonderveröffentlichung.

Döpke, J. (1996): ,Zu den konjunkturellen Bestimmungsgründen von Wohnungsbauinvestitionen", Die Weltwirtschaft, Vol. 132, No. 3, pp. 300-17.

Edey, M. (1994): „Costs and Benefits of Moving from Low Inflation to Price Stability“, OECD Economic Studies, No. 23, pp. 109-30.

Einaudi, L. (1953): „The Theory of Imaginary Money from Charlemagne to the French Revolution", in: F.C. Lane and J.S. Riemersma (eds.), Enterprise and Secular Change, pp. 229-61, Homewood, Illinois.

Expertenkommission Wohnungspolitik (1994): „Bericht der Expertenkommission Wohnungspolitik“, Deutscher Bundestag, Drucksache 13/159 v. 30.12.1994.

Feldstein, M. (1976): „Inflation, Income Taxes, and the Rate of Interest: A Theoretical Analysis“, The American Economic Review, Vol. 66, No. 5, pp. 809-20.

Feldstein, M. (1996): „The Costs and Benefits of Going From Low Inflation to Price Stability“, NBER Working Paper 5469.

Feldstein, M., J. Green and E. Sheshinski (1978): "Inflation and Taxes in a Growing Economy with Debt and Equity Finance, Journal of Political Economy, Part 2, pp. S53-S70.

Fischer, S. (1994a): „The Costs and Benefits of Disinflation“, in: J.A.H. de Beaufort Wijnholds, S.C.W. Eijffinger and L.H. Hoogduin (eds.), A Framework for Monetary Stability, pp. 31-42, Dordrecht: Kluwer Academic Publishers.

Fischer, S. (1994b): „Modern Central Banking“, in: F. Capie, Ch. Goodhart, S. Fischer, and N. Schnadt (eds.), The Future of Central Banking, Cambridge: Cambridge University Press.

Flaig, G. (1990): „Außenwirtschaftliche Impulse und privater Verbrauch“, in: J. Siebke (ed.), Monetäre Konfliktfelder der Weltwirtschaft, Schriften des Vereins für Socialpolitik, Neue Folge, Vol. 210, pp. 565-78.

Flaig, G. (1994): „Die Modellierung des Einkommens- und Zinsrisikos in der Konsumfunktion: Ein empirischer Test verschiedener ARCH-M-Modelle“, Volkswirtschaftliche Diskussionsreihe, No. 22, Institut für Volkswirtschaftslehre der Universität Augsburg. 
Friedman, M. (1969): „The Optimum Quantity of Money,“ in: M. Friedman, The Optimum Quantity of Money and Other Essays, Chicago: Aldine.

Goodhart, Ch. (1992): „The Objectives for, and Conduct of, Monetary Policy in the 1990s“, in: A. Blundell-Wignall (ed.), Inflation, Disinflation and Monetary Policy, pp. 314-39, Sydney: Ambassador Press.

Greenspan, A. (1989): „Statement before House Committee on Banking, Finance and Urban Affairs", January 24.

Grimes, A. (1991): „The Effects of Inflation on Growth: Some International Evidence", Weltwirtschaftliches Archiv, Vol. 127, pp. 631-44.

Hagen, J. von and M.J.M. Neumann (1996): „A Framework for Monetary Policy under EMU“, in: Deutsche Bundesbank (ed.), Monetary Policy Strategies in Europe, pp. 141-65, München: Verlag Franz Vahlen.

Hallman, J.J., R.D. Porter and D.H. Small (1989): „M2 per Unit of Potential GNP as an Anchor for the Price Level", Board of Governors of the Federal Reserve System, Staff Study No. 157, Washington, D.C.

Herrmann, H. (1996): „Stabilisierungspolitik, sacrifice ratio und geldpolitische Koordination in Europa“, Working Paper, Deutsche Bundesbank.

Howitt, P. (1990): „Zero Inflation as a Long-Term Target for Monetary Policy“, in: R.G. Lipsey (ed.), Zero Inflation: The Goal of Price Stability, Toronto: C.D. Howe Institute.

Issing, O. (1992): „Theoretical and Empirical Foundations of the Deutsche Bundesbank's Monetary Targeting“, Intereconomics, Vol. 27, pp. 289-300.

Issing, O. (1995): „Die Geldmengenstrategie der Deutschen Bundesbank“, in: J. Siebke and J. Thieme (eds.), Geldpolitik - Zwanzig Jahre Geldmengensteuerung in Deutschland, pp. 9-34, Baden-Baden: Nomos Verlagsgesellschaft.

Issing, O. (1996a): "Geldpolitik in einer Welt globalisierter Finanzmärkte", Außenwirtschaft, Vol. 51, No. III, pp. 295-309.

Issing, O. (1996b): „Staatsverschuldung als Generationenproblem“, in: U. Immenga, W. Möschel and D. Reuter (eds.), Festschrift für E.-J. Mestmäcker, pp. 191-209, Baden-Baden: Nomos Verlagsgesellschaft.

Issing, O. and K.-H. Tödter (1995): „Geldmenge und Preise im vereinigten Deutschland", in: D. Duwendag (ed.), Neuere Entwicklungen in der Geldtheorie und Währungspolitik, pp. 97-123, Berlin: Duncker \& Humblot.

Jahnke, W. (1996): „Probleme und Perspektiven in der Verwendung des makroökonometrischen Modells der Deutschen Bundesbank", Paper prepared for the workshop „Gesamtwirtschaftliche Modelle für die Bundesrepublik Deutschland: Erfahrungen und Perspektiven" of the Rheinisch-Westfälisches Institut für Wirtschaftsforschung (RWI), Essen, on November 29/30, 1996. 
King, M. (1996a): „How Should Central Banks Reduce Inflation? - Conceptual Issues", Bank of England Quarterly Bulletin, Vol. 36, No. 4, pp. 434-47.

King, M. (1996b): „Monetary Stability: Rhyme or Reason?", Bank of England, Speech at the Economic and Social Reseach Council's Seventh Annual Lecture, London, October 17, 1996.

King, M. and D. Fullerton (1983): „The Taxation of Income from Capital: A Comparative Study of the U.S., U.K., Sweden, and West Germany - The Theoretical Framework“, NBER Working Paper 1058.

Konieczny, J.D. (1994): „The Optimal Rate of Inflation: Competing Theories and Their Relevance to Canada", in: Bank of Canada (ed.), Economic Behaviour and Policy Choice Under Price Stability, Proceedings of a Conference held at the Bank of Canada, October 1993, Ottawa, pp. 1 - 46.

König, R. (1996): "The Bundesbank's Experience of Monetary Targeting", in: Deutsche Bundesbank (ed.), Monetary Policy Strategies in Europe, pp. 107-40, München: Verlag Franz Vahlen.

Lucas, R.E. Jr. (1990): „The Case for Stable, But Not Zero, Inflation“, in: R.C. York (ed.), Taking Aim: The Debate on Zero Inflation, pp. 65-80, Ottawa: C.D. Howe Institute.

Lucas, R.E. Jr. (1994): „On the Welfare Cost of Inflation“, NBER Publication No. 394.

Mishkin, F.S. (1992): „Is the Fisher Effect for Real?" Journal of Monetary Economics, Vol. 30, pp. 195-215.

Phelps, E.S. (1973): „Inflation in the Theory of Public Finance“, Swedish Journal of Economics, Vol. 75, pp. 67-82.

Romer, D. (1996): Advanced Macroeconomics, New York: McGraw-Hill.

Scarth, W. (1990): „Fighting Inflation: Are the Costs of Getting to Zero Too High?, in: R.C. York (ed.), Taking Aim: The Debate on Zero Inflation, pp. 65-80, Ottawa: C.D. Howe Institute.

Scarth, W. (1994): „Zero Inflation Versus Price Stability", in: Bank of Canada (ed.), Economic Behaviour and Policy Choice Under Price Stability, Proceedings of a Conference held at the Bank of Canada, October 1993, Ottawa, pp.89-119.

Scharnagl, M. (1996a): „Geldmengenaggregate unter Berücksichtigung struktureller Veränderungen an den Finanzmärkten", Discussion Paper 2/96, Volkswirtschaftliche Forschungsgruppe der Deutschen Bundesbank.

Scharnagl, M. (1996b): „Zur Stabilität der Geldnachfrage“, Discussion Paper for the Symposium „Zur Stabilität der Geldnachfrage“, Frankfurt, October 1996. 
Schelde-Andersen, P. (1992): „OECD Country Experiences with Disinflation“, in: A. Blundell-Wignall (ed.), Inflation, Disinflation and Monetary Policy, pp. 104-81, Sydney: Ambassador Press.

Sievert, O., H. Naust, D. Jochum, M. Peglow and Th. Glumann (1989): „Steuern und Investitionen, Teil 1 und Teil 2", Frankfurt am Main: Verlag Peter Lang.

Silberberg, E. (1978): The Structure of Economics, New York: McGraw-Hill.

Sinn, H.-W. (1987): "Inflation, Scheingewinnbesteuerung und Kapitalallokation", in: D. Schneider (ed.), Kapitalmarkt und Finanzierung, Schriften des Vereins für Socialpolitik, Neue Folge, Bd. 165, pp. 187-210.

Tanzi, V. (1980): "Inflation and the Personal Income Tax: An International Perspective", Cambridge: Cambridge University Press.

Taylor, J. (1992): „The Great Inflation, the Great Disinflation, and Policies for Future Price Stability", in: A. Blundell-Wignall (ed.), Inflation, Disinflation and Monetary Policy, pp. 9-35, Sydney: Ambassador Press.

Thornton, D.L. (1996): „The Costs and Benefits of Price Stability: An Assessment of Howitt's Rule", Federal Reserve Bank of St. Louis, Review, March/April, pp. 23-38.

Tobin, J. (1977): „How Dead is Keynes?“, Economic Inquiry, Vol. 15, pp. 459-68.

Tödter, K.-H. and H.-E. Reimers (1994): „P-Star as a Link Between Money and Prices in Germany", Weltwirtschaftliches Archiv, Vol. 130, No. 2, pp. 273-89.

Varian, H.R. (1984): Microeconomic Analysis, 2nd. ed., New York: W.W. Norton \& Company. 


\section{Appendix A: The welfare-theoretical approach}

Consider the following three points $\left(\mathrm{p}_{\mathrm{i}}, \mathrm{C}_{\mathrm{i}}\right)$ on the compensated demand function for retirement consumption, each corresponding to a specific type of regime (see Figure A1):

$\begin{array}{ll}\text { no tax, no inflation: } & \left(\mathbf{p}_{0}, \mathbf{C}_{0}\right) \\ \text { tax, no inflation: } & \left(\mathbf{p}_{1}, \mathbf{C}_{1}\right) \\ \text { tax and inflation: } & \left(\mathbf{p}_{2}, \mathbf{C}_{\mathbf{2}}\right)\end{array}$

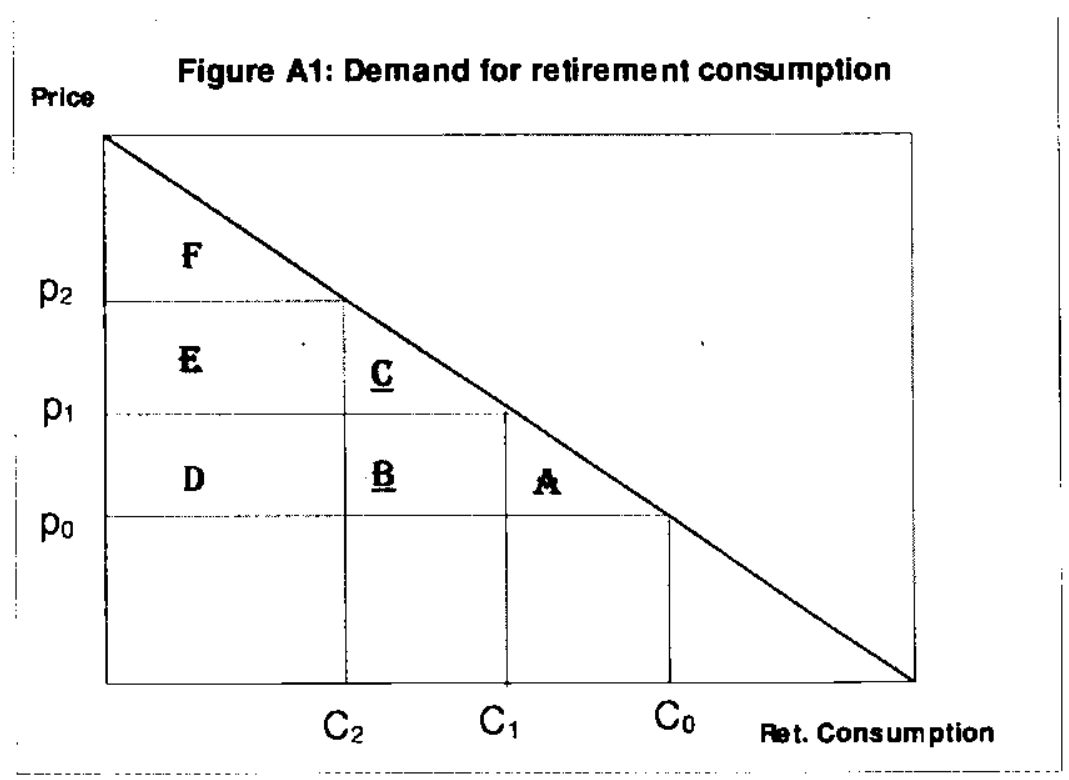

Without taxes and inflation consumers' surplus (CS) ${ }^{* 1}$ is the sum of the areas $A$ to Introducing capital income taxes in an environment of price stability moves the equilibrium point from $\left(p_{0}, C_{0}\right)$ to $\left(p_{1}, C_{t}\right)$ with less retirement consumption at a higher price. Consumers' surplus reduces to the area $\mathbf{C}+\mathbf{E}+\mathbf{F}$ and tax revenues (TR) corresponding to the area $\mathbf{B}+\mathbf{D}$ are created. The difference, the triangle $\mathbf{A}$, is a

\footnotetext{
${ }^{1}$ Problems with the concept of consumers' surplus as a measure of welfare effects are discussed in detail by Sitherhero (1978)
} 
deadweight loss (DWL); it is the reduction of consumers' surplus which is not compensated by higher tax revenues. The DWL per D-Mark of taxes raised is

$$
\lambda_{C}=\mathbf{A} /(\mathbf{B}+\mathbf{D}) \text {. }
$$

Introducing both, taxes and inflation, moves the equilibrium point to $\left(\mathrm{p}_{2}, \mathrm{C}_{2}\right)$ with a reduced consumption level at a higher price. The remaining consumers' surplus is the area $\mathbf{F}$, whereas tax revenues correspond to the rectangle $\mathbf{D}+\mathbf{E}$. The deadweight loss increases to the triangle $\mathbf{A}+\mathbf{B}+\mathbf{C}$. The following table summarizes the welfare acounting for the three regimes:

\begin{tabular}{|l|c|c|c|}
\hline Regime & $\mathbf{C S}$ & TR & DWL \\
\hline no tax, no inflation & $\mathbf{A}+\mathbf{B}+\mathbf{C}+\mathbf{D}+\mathbf{E}+\mathbf{F}$ & - & - \\
\hline tax, no inflation & $\mathbf{C}+\mathbf{E}+\mathbf{F}$ & $\mathbf{B}+\mathbf{D}$ & $\mathbf{A}$ \\
\hline tax and inflation & $\mathbf{F}$ & $\mathbf{D}+\mathbf{E}$ & $\mathbf{A}+\mathbf{B}+\mathbf{C}$ \\
\hline
\end{tabular}

Hence, moving from the equilibrium with taxes and inflation to price stability increases consumers' surplus by the area $C+E_{n}$ and changes tax revenues by the amount $(\mathbf{B}+\mathbf{D})-(D+E)=\mathbf{B}-\mathbf{E}$. The welfare difference between the two regimes is a reduction of deadweight loss, i.e. a deadweight gain, measured by the trapezoid $\mathbf{B}+\mathbf{C}$.

Assuming that the government faces a strict budget constraint at the margin, the change in tax revenues needs to be compensated by increasing (if negative) or decreasing (if positive) other taxes. Denoting the deadweight loss per D-Mark of some compensating tax by $\lambda$, then

$$
G_{C}=(B+C)+\lambda(B-E)
$$

is the net deadweight gain of price stability. 


\section{Appendix B: Taxation of corporate profit}

\begin{tabular}{|c|c|c|c|c|c|c|c|c|c|c|}
\hline & & \begin{tabular}{|c|} 
Rate") \\
$(\%)$
\end{tabular} & $\begin{array}{l}\text { Distributed } \\
\text { profit of a } \\
\text { incorporat } \\
\text { enterprise }\end{array}$ & dom. & $\begin{array}{c}\text { Rate*) } \\
(\%)\end{array}$ & $\begin{array}{l}\text { Income o } \\
\text { partnersh }\end{array}$ & $\begin{array}{l}\text { of a } \\
\text { hip }\end{array}$ & $\mid \begin{array}{c}\text { Rate*) } \\
(\%)\end{array}$ & $\begin{array}{l}\text { Retained } \\
\text { profits of } \\
\text { dom. Inco } \\
\text { enterprise }\end{array}$ & \\
\hline a) & Gross rate of return (\%) & & 10.80 & & & 10.80 & & & 10.80 & \\
\hline b) & Trading capital (DM) & & 925.93 & & & 925.93 & & & 925.93 & \\
\hline c) & Gross profit (DM) & & 100.00 & 101.00 & & 100.00 & 101.00 & & 100.00 & 101.00 \\
\hline d) & Tax on trading capital (of b) & 0.80 & -7.41 & -7.41 & & -7.41 & -7.41 & & -7.41 & -7.41 \\
\hline e) & Trade earnings tax (of $c+d)$ & 16.67 & -15.43 & -15.60 & & -15.43 & -15.60 & & -15.43 & -15.60 \\
\hline f) & Gross dividend / taxable income & & 77.16 & 77.99 & & 77.16 & 77.99 & & 77.16 & 77.99 \\
\hline g) & Corporation tax (of $t)$ & 30.00 & -23.15 & -23.40 & & & & 45.00 & -34.72 & -35.10 \\
\hline i) & Trade earnings tax $(o f f+g)$ & 25.00 & -13.50 & -13.65 & & & & & & \\
\hline j) & Solidarity surcharge (of $g+i$ ) & 7.50 & -2.75 & -2.78 & & & & & -2.60 & -2.63 \\
\hline k) & Corp. property tax (of b) & 0.45 & -4.17 & -4.17 & & & & & -4.17 & -4.17 \\
\hline l) & Income tax (of n) & 35.00 & -27.01 & -27.30 & & -27.01 & -27.30 & & & \\
\hline m) & Solidarity surcharge (of 1) & 7.50 & -2.03 & -2.05 & & -2.03 & -2.05 & & & \\
\hline n) & Property tax (of b) & 0.50 & -4.63 & -4.63 & 0.38 & -3.47 & -3.47 & & & \\
\hline o) & Tax credit $(g+i+j)$ & & 39.40 & 39.83 & & & & & & \\
\hline p) & Net profit (DM) & & 39.33 & 39.85 & & 44.66 & 45.18 & & 35.67 & 36.10 \\
\hline q) & Net rate of retum (\%) & & 4.25 & & & & & & & \\
\hline r) & Tax burden (DM) & & 60.67 & 61.15 & & 55.34 & 55.82 & & 64.33 & 64.90 \\
\hline & Marginal tax burden (\%) & & . & 48.02 & & & 48.02 & & & 56.98 \\
\hline
\end{tabular}

") Effective calculated rates, relative to the respective basis for assessment. 


\section{Appendix C: An overlapping generations model}

Consider the following simple overlapping generations (OLG) model with a constant relative risk aversion (CRRA) - utility function:

$$
\operatorname{Max} \frac{C_{y t}^{1-\Psi}}{1-\Psi}+s \frac{C_{O t+1}^{1-\Psi}}{1-\Psi} ; \quad s=(1+\rho)^{-T}, \quad \rho>-1, \quad \Psi>0
$$

subject to

$$
\begin{array}{ll}
C_{y t}+S_{y t}=W_{t} & \\
C_{o t+1}=\frac{1}{p} S_{y t}, & p=(1+r)^{-T}
\end{array}
$$

$\mathrm{C}_{\mathrm{y}}$ denotes consumption of the young generation and $\mathrm{C}_{0}$ is their retirement consumption; $S_{y}$ represents savings of the young and $W$ is their (exogenous) wage income. Moreover, the parameter $\rho$ represents the rate of time preference, $1 / \Psi$ measures the intertemporal elasticity of substitution. ${ }^{* 1}$ Equation (C3) corresponds to equation (3.1) in the main text. The solution of this model is:

$$
\begin{aligned}
& C_{y t}^{*}=W_{t} \Omega \quad \text { with } \Omega=\left[1+p^{1-1 / \Psi} s^{1 / \Psi}\right]^{1} \\
& S_{y t}^{*}=W_{t}(1-\Omega) \\
& C_{o t+1}^{*}=\frac{1}{p} W_{t}(1-\Omega)
\end{aligned}
$$

$\Omega$ is the propensity to consume of the young generation out of wage income. Assuming that real wages grow with the rate $n+g$, from (C3) we can write consumption of the presently old as the sum of their previous period's savings and the accumulated interest income of these savings as

\footnotetext{
${ }^{-1}$ See Blanchard and Fischer (1989) and Romer (1996). In the special case $\Psi \rightarrow 1$, the instantaneous utility function cimnlifies on the forarithmic wtilitu function.
} 


$$
C_{\text {ot }}=\frac{1}{p} S_{y t-1}=\frac{q}{p} S_{y t} ; \quad q=(1+n+g)^{-T}
$$

(Dis-) Saving of the presently old equals interest income minus consumption:

$$
S_{\text {ot }}=\frac{q}{p}(1-p) S_{y t}-C_{o t}=-q S_{y t}
$$

Total savings (in period t) are equal to savings of the young plus savings of the presently old:

$$
\mathrm{S}_{\mathrm{Nt}}=\mathrm{S}_{\mathrm{yt}}+\mathrm{S}_{\mathrm{ot}}=(1-\mathrm{q}) \mathrm{S}_{\mathrm{yt}}
$$

In the period 1985 to 1994 the average annual growth rate of real wages was $\mathrm{n}+\mathrm{g}=2.2 \%^{2}$ which, discounted over a generation of $\mathrm{T}=27$ years, yields $\mathrm{q}=0.556$, implying $S_{N}=0.444 S_{y}$. Private savings accounted for $9.3 \%$ of GDP on average between 1991/95. Hence, from (C9) we get $\mathbf{S}_{\mathbf{y}}=0.209$ GDP.

Alternatively, equation (C5) can be used to calculate savings of the young. This

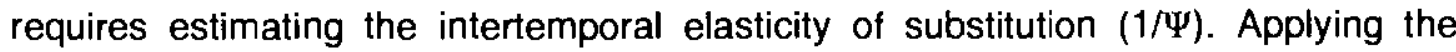
Euler-equations approach, Flaig $(1990,1994)$ obtains an intertemporal elasticity of substitution (IES) in the range of 0.24 to 0.43 from aggregate consumption data for Germany. These low values imply a negative interest rate elasticity of savings. However, estimates of the IES by the Euler-equations approach from aggregate data are likely to be biased downward. Attanasio and Weber (1995, p. 569) show "that the bias introduced by using aggregate consumption data to estimate the elasticity of intertemporal substitution can be substantial". In particular, aggregate data may imply an elasticity of substitution close to zero, even if it is one at the micro-level. This is confirmed in an empirical study by Beaudry and Wincoop (1996) for the US based on a panel of state data. They find "that the IES for nondurables consumption is

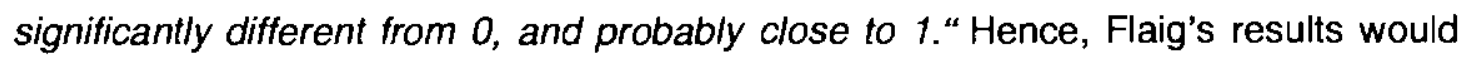

\footnotetext{
${ }^{2}$ Due to German unification and other factors, the growth rate of real wages in West Germany in the period 1990 to $1994(1.4 \%)$ was exceptionally low and understates the long-term equilibrium growth rate. For this reason we use the average growth rate of the last ten years.
} 
seem to be consistent with $1 / \Psi=4 / 3$. Using the real interest rate calculated in the main text, i.e. $r=r_{2}=4.24 \% \quad(p=0.326)$ and assuming a rate of time preference of $\rho=2.5 \%$ ( $s=0.513$ ), yields $\Omega=0.626$. Wages in West Germany accounted for $\alpha=56 \%$ of GDP on average over the period 1990 to 1994 . Hence, from (C5) we obtain $S_{\mathbf{y}}=0.209$ GDP, which matches the result obtained via (C9).

Differentiating equation (C5) with respect to the interest rate yields the interest rate elasticity of the savings of the young:

$$
\eta_{S r}=\left(\frac{1}{\Psi}-1\right) \Omega \frac{r T}{1+r}
$$

This elasticity is positive if the elasticity of substitution $(1 / \Psi)$ is greater than 1 . Using the same parameter values as before, we obtain an estimate of the interest rate elasticity of savings of the young of $\eta_{s r}=\mathbf{0 . 2 3}$. 


\section{Appendix D: Assumptions for calculating the benefits}

\section{Fiscal policy parameters}

Average tax rate on distributed profits (\%)

Marginal tax rate on distributed profits (\%)

48.00

35.00

Marg. income tax rate (incl. solidarity surcharge) (\%)

37.60

Property tax rate (\%)

Effective tax rate on capital gains (\%)

Auerbach-Elasticity

Useful fiscal economic life of fixed assets (years)

Tax concession as $\%$ of the acquisition costs

of owner-occupied housing

Marginal excess burden of taxation

0.57

10.00

\section{Financial parameters}

Real gross rate of return (\%)

Discounting period (years)

Ratio of corporate debt to capital (\%)

45.00

40.00

Ratio of equity and bonds to net wealth

43.00

60.00

of private households (\%)

Depreciation and maintennance costs of housing (\%)

4.00

4.00

Nominal mortgage rate (\%)

8.50

7.20

Ratio of mortgage to value of owner-occupied houses (\%)

60.00

$20 / 50$

Value of owner-occupied housing as \% of GDP

170.00

105.00

Debt service as \% of public debt

7.80

8.50

Public debt as \% of GDP

\section{Macroeconomic relations}

Growth rate of real wages and resp. of GDP (\%)

Ratio of wages to GDP (\%)

Ratio of savings to GDP (\%)

9.30

Ratio of money stock (currency in circulation

and minimum reserves) as \% of GDP

\section{Behavioural coefficients}

Interest rate elasticity of savings

Comp. interest elasticity of investment in housing capital

0.25

$(0 ; 0,4 ; 1,0)$

Interest rate elasticity of money demand

0.25

0.80

0.25

0.20

*) Feldstein (1996) 
Appendix E: Sensitivity calculations

\section{Effectlve inflation rate (\%)}

\section{Fiscal policy parameters}

Average tax rate on distributed profits (\%)

Marginal tax rate on distributed profits (\%)

Marg. income tax rate (incl. solidarity surcharge) (\%)

Property tax rate (\%)

Effective tax rate on capital gains (\%)

Auerbach-Elasticity

Useful fiscal economic life of fixed assets (years)

Tax concession as $\%$ of the acquisition costs

of owner-occupied housing

Marginal excess burden of taxation

\section{Financial parameters}

Real gross rate of return (\%)

Discounting period (years)

Ratio of corporate debt to capital (\%)

Ratio of equity and bonds to net wealth

of private households (\%)

Depreciation and maintenance costs of housing (\%)

Nominal mortgage rate (\%)

Ratio of mortgage to value of owner-occupied houses (\%)

Value of owner-occupied housing as \% of GDP

Debt service as $\%$ of public debt

Public debt as $\%$ of GDP

\section{Macroeconomic relations}

Growth rate of real wages and resp. of GDP (\%)

Ratio of wages to GDP (\%)

Ratio of savings to GDP (\%)

Ratio of money stock (currency in circulation

and minimum reserves) as \% of GDP

\section{Behavioural coefficients}

Interest rate elasticity of savings

Comp. interest rate elasticity

of investment in housing capital

Interest rate elasticity of money demand

\begin{tabular}{cccccc} 
bench- & \multicolumn{2}{c}{ Assumptions } & \multicolumn{2}{c}{ Results } \\
mark & A & B & A & B \\
2.00 & 1.50 & 2.50 & 1.16 & 1.61
\end{tabular}

1.61

$\begin{array}{lllll}60.70 & 57.70 & 63.70 & \mathbf{1 . 3 1} & \mathbf{1 . 5 2} \\ \mathbf{4 8 . 0 0} & 45.00 & 51.00 & 1.38 & 1.45 \\ 37.60 & 32.60 & 42.60 & 1.35 & 1.47\end{array}$

10.00

13.00

7.00

3.00

1.32

1.51

2.00

1.00

$1.40 \quad 1.42$

10.80

27.00

45.00

9.80

11.80

1.40

1.42

24.00

30.00

1.30

40.00

1.32

48.00

1.50

38.00

4.00

5.00

3.00

8.50

60.00

9.50

65.00

170.00

150.00

7.50

$1.40 \quad 1.42$

$1.40 \quad 1.43$

7.80

6.80

55.00

1.40

1.43

190.00

$\begin{array}{ll}1.40 & 1.42\end{array}$

48.00

51.00

8.80

$1.41 \quad 1.41$

$\begin{array}{lll}45.00 & 1.40 & 1.42\end{array}$

2.20

2.70

1.70

1.32

1.51

56.00

9.30

53.00

59.00

1.36

1.46

9.00

10.00

10.30

$1.34 \quad 1.47$

$8.00 \quad 1.41 \quad 1.42$

$\begin{array}{lllll}0.25 & 0.10 & 0.40 & 1.11 & \mathbf{1 . 7 4} \\ 0.25 & 0.15 & 0.35 & 1.37 & 1.45 \\ & & & & \\ 0.25 & 0.10 & 0.40 & 1.40 & 1.43\end{array}$




\section{Appendix F: An OLG model with transfers}

The analysis so far implicitly assumed that a fully funded system is in place for providing old age pensions. The purpose of this appendix is to take into account that actually many retirees receive a significant amount of exogenous income through an unfunded (,pay as you go“) system.

We retain the utility function (C1) of Appendix C, i.e.,

$$
\operatorname{Max} \frac{C_{y t}^{1-\Psi}}{1-\Psi}+s \frac{C_{\text {ot }+1}^{1-\Psi}}{1-\Psi} ; \quad s=(1+\rho)^{-T}, \quad \rho>-1, \quad \Psi>0
$$

but change the budget constraints for the young (C2) und the old (C3) generation to

$$
\begin{gathered}
C_{y t}+S_{y t}=W_{t}(1-\tau-\gamma)+Z_{t} \\
C_{o t+1}=\frac{S_{y t}}{p}+\frac{\gamma W_{t}}{q}-\frac{R_{t}}{q}
\end{gathered}
$$

We assume that the total wage income accrues to the young generation, as well as all government transfers, except pension payments. On the other hand, the old (retired) generation receives all non-wage income plus the pension payments. Hence, in equation (F2), W represents the (exogenous) gross wage income, including employers' contributions to social security (i.e. to the pension fund and to the health and unemployment insurance); $\tau$ is an average 'tax' rate which comprises employee's and employer's contributions to the social security system except for contributions to the pension fund; $\gamma$ is the rate paid (by both, employers and employees) to the pension fund; $Z$ is the amount of net government transfers received by the young generation. In equation (F3), $\gamma \mathrm{W} / \mathrm{q}$ is the amount of pensions received by the old generation; $R$ is the net amount of transfers left by the old generation. We assume that this amount is channelled through the government sector such that there is no direct link between the amount bequeathed by the old $(R)$ and the amount of transfers received by the young $(Z)$. Note, that in contrast to 
the rate of return $(r)$ of savings of the young, the implicit rate of return of the contributions to the "pay as you go" - pension fund is the real growth rate $n+g . " 1$

Solving (F1) subject to the restrictions (F2) and (F3) yields the following optimal consumption and saving schedules:

$$
\begin{aligned}
& C_{y t}^{\star}=\left[W_{t}(1-\tau-\gamma)+Z_{t}\right] \Omega+\frac{p}{q}\left[\gamma W_{t}-R_{t}\right] \Omega \\
& S_{y t}^{\star}=\left[W_{t}(1-\tau-\gamma)+Z_{t}\right](1-\Omega)-\frac{p}{q}\left[\gamma W_{t}-R_{t}\right] \Omega \\
& C_{o t+1}^{\star}=\frac{1}{p}\left[W_{t}(1-\tau-\gamma)+Z_{t}\right](1-\Omega)-\frac{1}{q}\left[\gamma W_{t}-R_{t}\right](1-\Omega)
\end{aligned}
$$

The parameter $\Omega$ is defined in eq. (C4) of Appendix C. Assuming, that the growth rate of real wages $(W)$ and transfers $(Z, R)$ is $n+g$, consumption of the presently old (eq. C7) becomes:

$$
\mathrm{C}_{\mathrm{ot}}=\frac{\mathrm{q}}{\mathrm{p}} \mathrm{S}_{\mathrm{yt}}+\gamma \mathrm{W}_{\mathrm{t}}-\mathrm{R}_{\mathrm{t}}
$$

The equations for savings of the presently old (C8) and total private savings (C9) remain valid, however:

$$
\begin{aligned}
& S_{\mathrm{ot}}=-q S_{y t} \\
& S_{N t}=(1-q) S_{y t}
\end{aligned}
$$

These relationships imply the following accounting table for period $t$ :

Table F1: Income and expenditure of the private sector

\begin{tabular}{|c|c|c|c|}
\hline Item & Young & Presently Old & Total \\
\hline Saving & $\mathrm{S}_{\mathrm{y}}$ & $\mathrm{S}_{\mathrm{o}}$ & $\mathrm{S}_{\mathrm{N}}$ \\
Consumption & $\mathrm{C}_{\mathrm{y}}$ & $\mathrm{C}_{\mathrm{o}}$ & $\mathrm{C}_{\mathrm{N}}$ \\
\hline Total & $\mathrm{W}_{\mathrm{n}}$ & $\mathrm{Q}_{\mathrm{n}}$ & $\mathrm{Y}_{\mathrm{D}}$ \\
\hline
\end{tabular}

\footnotetext{
${ }^{*}$ In a fully funded system we have $\mathrm{p}=\mathrm{q}$ and $\gamma \mathrm{W} / \mathrm{p}$ drops out of eq. (F3) when (F2) is inserted. Hence, the optimal savings and consumption plan is independent of contributions to the pension fund $(\gamma)$ in a fully funded svetem.
} 
The higher real interest rate increases savings of the young only by $0.5 \%$ of GDP and reduces consumption of the young accordingly (note that the net income of the young is given exogenously). ${ }^{* 1}$ Because dis-saving of the old rises by $0.3 \%$ of GDP, total private savings increase only by $0.2 \%$ of GDP. The biggest change occurs for consumption of the old: this aggregate increases from $29.3 \%$ to $35.8 \%$ of GDP.

What are the welfare consequences of this move from 2 percent inflation to price stability? To re-calculate the benefits of price stability along the lines of section 3 , we have to recognize that equation $(3.1)(\mathrm{S}=\mathrm{pC})$ changes to $(\mathrm{F} 3)$, which is reproduced here for concenience, dropping subscripts, as:

$$
S=p C-\frac{p}{q}(\gamma W-R)
$$

From this equation we derive the following expression for the price elasticity of savings:

$$
\eta_{S p}=-\left[\frac{W(1-\tau-\gamma)+Z}{S} \eta_{\Omega p}+\frac{p}{q} \frac{\gamma W-R}{S}\left(1+\eta_{\Omega p}\right)\right] \Omega
$$

where

$$
\eta_{\Omega p}=\left(\frac{1}{\Psi}-1\right)(1-\Omega)
$$

The compensated price elasticity of retirement consumption becomes:

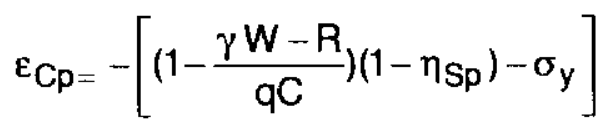

with

$$
\sigma_{y}=\frac{d(p C)}{d W}=(1-\Omega)\left[1-\tau-\gamma\left(1-\frac{p}{q}\right)\right]
$$

\footnotetext{
*I This suggests that the change of the marginal product of capital would be small, justifying our assumption of a
} 
Introducing the parameter values used above produces $\eta_{\Omega p}=0.125, \eta_{S p}=-0.170$, $\left(\eta_{S_{r}}=0.186\right), \sigma_{y}=0.246$, and $\varepsilon_{C p}=-0.987$. This, in turn, yields $C_{1}-C_{2}=7,82 \%$ of GDP as the induced change of old-age consumption.

Using (3.3) to (3.7) we obtain the following areas under the compensated demand function:

$$
\begin{aligned}
\mathrm{A} & =5.21 \% \text { of GDP } \\
\mathrm{B} & =1.68 \% \text { of GDP } \\
\mathrm{C} & =\mathbf{0 . 1 9} \% \text { of GDP } \\
\mathrm{D} & =11.30 \% \text { of GDP } \\
\mathrm{E} & =2.58 \% \text { of GDP }
\end{aligned}
$$

The net benefit of price stability in this extended model incorporating intergenerational transfers turns out as

$$
\mathrm{G}_{\mathrm{C}}=1.87+0.40^{*}(-0.91)=1.50 \% \text { of } \mathrm{GDP}
$$

Hence, the gain from improved intertemporal allocation of consumption and saving is almost the same as that obtained on the basis of the simpler model in the body of the paper. 